Nikolaus Leo Overtoom*

\title{
The Power-Transition Crisis of the 160s-130s BCE and the Formation of the Parthian Empire
}

https://doi.org/10.1515/jah-2018-0024

\begin{abstract}
Alexander the Great's conquests ushered in the Hellenistic era throughout the ancient Mediterranean and Middle East. In this period, the Seleucids, one of most successful of the Successor dynasties, ruled over most of the Middle East at the height of their power. Yet two rising powers in the ancient world, Rome and Parthia, played a crucial role in the decline and eventual fall of the Seleucids. In a prior article, I argued that geopolitical developments around the Eastern Mediterranean in the middle third century BCE were indirectly responsible for the emergence of the Parthian state in Iran. Disastrous military conflicts at home and abroad in the west caused a sudden decline of Seleucid power in the 240s-230s, triggering what political scientists call a power-transition crisis. This article utilizes similar approaches to historical analysis and International Relations theory to contend that, after a period of recovery, a further sudden decline of Seleucid power in the 160s-130s triggered another power-transition crisis that brought an end to Seleucid hegemony over the Middle East permanently. The crisis facilitated the rapid transformation of the Parthian state from a minor kingdom to a major empire, drastically changing the international environment of the ancient world.
\end{abstract}

Keywords: Parthians, Seleucids, Middle East, Warfare, International Relations

At the dawn of the third century BCE, the Seleucid Empire ruled the Middle Eastern lands conquered by Alexander the Great. Alexander and his Successors ushered in the Hellenistic era, where Greek culture and the Greek language heavily influenced these conquered eastern territories. What we may call the "Hellenistic Middle East" represents a territorial space roughly defined by the Levantine coast, Syria, northern Mesopotamia, and Armenia in the west, and the central Asian steppe and the Indus River valley in the east. These were the lands ruled over by the Seleucids at the height of their power. The Seleucid Empire was one of the largest and most culturally diverse states in the world. Its wealth was immense,

*Corresponding author: Nikolaus Leo Overtoom, Department of History, Wilson-Short Hall, Room 301, Washington State University, Pullman, WA 99164, E-Mail: novertoom@unm.edu 
and its frontiers were expansive. Yet the momentous size and diversity of the empire was its biggest liability. Only the strongest of kings at the best of times could hold such an extensive and disparate empire together. ${ }^{1}$ Unfortunately for the Seleucids, such men were a rarity.

The Seleucid Empire had a difficult existence, continually suffering dynastic turmoil and bitterly fighting with numerous rival Hellenistic states (most notably Ptolemaic Egypt). Yet two rising powers in the ancient world, Rome and Parthia, played a crucial role in the decline and eventual fall of the Seleucids. Although generally scholars continue to maintain that the Romans were primarily responsible for the "irreversible weakening of the Seleukid Kingdom," it was in fact the Parthians (also known as the Arsacids) who eventually damaged Seleucid power irreparably. ${ }^{2}$

The people later collectively recognized as the Parthians began as a nomadic tribe known as the Parni, who in the early third century came to settle in what is today western Turkmenistan. ${ }^{3}$ The Parni had been moving southward and westward for decades in search of a secure and prosperous home (Just. Epit. 41.1.1011). For several more decades they tried to gain access to the well-positioned, wealthy lands of the Iranian plateau for protection from violent neighbors, increased state security, political opportunity, and the ability to establish and cultivate a strong powerbase. ${ }^{4}$ Finally, a geopolitical crisis throughout the Hellenistic Middle East, where the Seleucid Empire fractured under the pressures of civil war, rebellion, and invasion, facilitated the Parni's conquest of northeastern Iran. ${ }^{5}$ Once in power, the victorious Parni quickly convinced the Parthian aristocracy in the region to support them against the interests of the Seleucid state and its officials. ${ }^{6}$

The establishment of the Parthian state created a major rivalry between the Seleucids and Parthians that lasted one-and-a-half centuries and ended with the Parthian conquest of most of the former Seleucid Empire. ${ }^{7}$ The Roman historian

1 Grainger (2015), 66-67.

2 Scholars generally overstate the severity of Seleucid decline immediately following Magnesia. Matyszak (2008), xvii-xx; Gabelko (2009), 52; Howarth (2013), 30; Dąbrowa (2014), 61; Sampson (2015), 22, 27-28, 44-45; Olbrycht (2016b), 459; Gregoratti (2017b), 127. Contra Gruen (1984), 671; Habicht (1989), 369ff.; Sherwin-White and Kuhrt (1993), 217-229; Grainger (2002), 350-351; Strootman (2004).

3 The Parni likely were part of the larger Dahae confederacy on the southern Central Asian steppe. Olbrycht (2003), 71-72; Assar (2011), 113; Olbrycht (2015b), 257-258; Balakhvantsev (2017), 24-61.

4 Overtoom (2016a).

5 Overtoom (2016a).

6 Frye (1984), 208; Shahbazi (1986); Olbrycht (2003), 73-75.

7 Overtoom (2016c). 
Justin (Epit. 41.1-3) viewed the Parthians as a powerful and resilient people, who had benefitted from great leadership, determination, and adaptability, allowing them to survive their humble origins, outlast numerous better-situated competitors, and emerge as the last rivals of Rome. ${ }^{8}$ This article will address the circumstances in which the Parthian state emerged for the first time as a peer rival of the Seleucid Empire during another period of crisis throughout the Hellenistic Middle East in the 160s-130s, utilizing International Relations theory as a theoretical framework to help better understand the rapidly evolving geopolitical developments of this period. ${ }^{9}$

It was in this period that the Parthians not only became determined to establish a level of regional security that assured their survival and protection on the Iranian plateau, but also became determined to dominate the entire Hellenistic Middle East. ${ }^{10}$ Under Mithridates I and his immediate successors, the Parthian kingdom transformed into what International Relations theorists call an "unlimited revisionist state."11 The Parthians were no longer content to share power within the Hellenistic Middle East, and they suddenly and with great energy began to invade and occupy neighboring regions at the direct expense of the Seleucids. ${ }^{12}$ The Parthians for the first time established an empire that became the most threatening rival of the Seleucids in the Hellenistic Middle East, and this new rivalry between the Seleucids and Parthians drastically shaped the international environment of the Hellenistic Middle East for the next several decades. ${ }^{13}$

8 Note Olbrycht (2003); Hill (2013); Overtoom (2016c), 143; Overtoom (2017a); Engels (2017), 55-56; Müller (2017b).

9 In reconstructing Parthian history, Greek and Roman literary sources dominate the narrative and often treat the Parthians hostilely or cursorily. It is vital to utilize all available literary, epigraphical, and numismatic evidence to establish the most probable reconstruction of events. Although it is not a panacea and must be utilized carefully within the parameters of our surviving literary and physical evidence, the application of International Relations theory helps provide a fuller appreciation of the geopolitical development of the Parthian state and may help us overcome some of the limitations of our sources. For recent discussions of Parthian sources, note Lerouge-Cohen (2007), 26-37; Dąbrowa (2010), 123; Hauser (2013), 729-730; Sampson (2015), 186-199; Rezakhani (2016); Wiesehöfer and Müller (2017).

10 The sources emphasize the heightened aggression and military expansion of the Parthians in this period. Just. Epit. 41.1.6-9, 5.9, 6.1-3, 6-8; Moses 2.2; Strabo 11.7.1, 8.1, 8.8; 9.2, 11.2; Sachs and Hunger (1996), no. -140A, no. -140C.

11 For unlimited revisionist states, see Kissinger (1957).

12 For the argument that war is a normal aspect of state interaction under these pressures, see Waltz (1959), 160; (1979), 102; (1988), 620-621; (2000), 8; Wight (1978), 137. This was true in the ancient world as well. Eckstein (2005), 484-485.

13 Assar (2011), 117; Overtoom (2016a), 1000; (2016c), Chs. 2-3; (2018); (2019). For bipolarity, see Waltz (1979), 161-170; Copeland (1996); Geller and Singer (1998), 115-117; Eckstein (2006), 23, 67. 


\section{IR Theory and the Rise of Parthia}

Although the Parthian state certainly was quite different than modern nationstates, around which International Relations theory developed, it was a nuanced and highly effective imperial power that rivalled the abilities and accomplishments of any ancient state. The growth and development of the Parthian state, which scholars usually discuss in the traditional terms of political history - good leadership, the inclusiveness of Parthian rule, Parthian adaptability, or the declining strength of Parthia's neighbors - is better understood with International Relations theory, specifically the theoretical framework of Realism. ${ }^{14}$ Realism emphasizes the unforgiving and competitive nature of interactions between states within an international system of states that lacks enforceable international law and/or central authority, known as interstate anarchy. ${ }^{15}$ This article employs Realist Theory (specifically a Neorealist or "structural" approach to international relations, which is the study of how system structures affect international behaviors and outcomes) as a framework to help provide greater perspective and a more expansive understanding of state decision-making and interaction in the ancient world. ${ }^{16}$ In this endeavor I share Eckstein's preference for the use of the subschool of Realist theory called "offensive" Realism when analyzing ancient international environments because of the comparatively primitive and violent characteristics of these environments in the ancient world. ${ }^{17}$ Offensive Realism maintains that states seek to maximize their security and power through domination and hegemony because of the anarchic nature of many interstate systems (or international communities in which states interact and compete) ${ }^{18}$ Systems of militarized interstate anarchy were common in the ancient world, including the systems that developed in the Hellenistic Middle East.

In the 240s-230s, Seleucid control of their eastern lands declined suddenly as a series of costly wars against Ptolemaic Egypt and dynastic disputes sapped Seleucid strength. In particular the sudden death of Antiochus II (in 246), the Seleucid defeat in the Third Syrian War (246-241), and the subsequent civil war for the

14 Wolski (1967); (1981); Keall (1994), 271-272; Olbrycht (2003), 98-99; (2010b), 147; (2016a); (2017); Grajetzki (2011), 11; Shayegan (2011), 328; Dąbrowa (2011); (2013); Daryaee (2015), 287; Overtoom (2016a); (2016c); Wiesehöfer (2016), 217-218, 227; Gregoratti (2016b), 86-89; (2017a) .

15 For interstate anarchy, see Waltz (1959), 159-160; Schuman (1969), 485; Aron (1973), 6; Wight (1978), 101; Waltz (1979), 76, 102, 127; Gilpin (1981), 7; Schelling (2000), 182.

16 Waltz (1979), Ch. 5-6 was the most influential advocate of Neorealism. Note Eckstein (2005); (2006); (2012); (2013); Overtoom (2016a).

17 See Eckstein (2006), 6 n. 9, 29-33.

18 For offensive Realism, see Mearsheimer (2001), Ch. 2. 
throne (ca. 240-236) severely damaged the reputation and military might of the Seleucid Empire. ${ }^{19}$ This unexpected decline of Seleucid power in the 240 s caused what international relations theorists call a "power-transition crisis" (or a sudden and dramatic fluctuation of a state's power within an interstate system) in the Hellenistic Middle East. ${ }^{20}$ Although a power-transition crisis does not in and of itself cause war, it makes hegemonic war, which is a large-scale war that reorders or creates a new interstate structure that better reflects the realities of power distribution and balance of power within the system, more likely because it destabilizes the interstate system and brings power relations into question. ${ }^{21}$ This is precisely what happened in the 240s-230s as Parthia and Bactria emerged as rival powers to the Seleucid Empire on the Iranian plateau. ${ }^{22}$

With the emergence of rival states within the Hellenistic Middle East in the middle third century, the international environment once dominated by the Seleucid Empire suddenly and drastically changed..$^{23}$ Parthia in northeastern Iran and Bactria in Afghanistan challenged Seleucid hegemony on the Iranian plateau, and the major interstate system, which had incorporated all the Greek lands of the eastern Mediterranean and the Persian-held regions of the Middle East since the Persian Wars, abruptly and effectively split. ${ }^{24}$ What International Relations theorists call an interstate system of "tripolarity" (or the rivalry of three dominant states) between Antigonid Macedon, Ptolemaic Egypt, and the Seleucid powerbase in Syria remained in place in the west in the new, more focused "Eastern Mediterranean interstate system." 25 Yet a turbulent and rather ambiguous tripolarity between Parthia, Bactria, and the Seleucid Empire also emerged in the east in what we may call the newly formed "Iranian interstate system."26

19 Lerner (1999), 30 attributes the decline of Seleucid authority over eastern Iran directly to these two conflicts.

20 For power-transition theory, see Lemke and Kugler (1996), 3-33; Geller and Singer (1998), 7275; Tammen (2000). For power-transition crisis because of a deteriorating state, see Organski and Kugler (1980). For power-transition crisis because of an ascending state, see Gilpin (1981); (1988), 602. For examples of power-transition crisis in antiquity, see Eckstein (2006), 23-24, 105, 114, 269; (2012), 4 et passim; Overtoom (2016a).

21 Levy (1985), 365-366; Gilpin (1988), 591-606.

22 Overtoom (2016a).

23 Overtoom (2016a).

24 In a previous article, I referred to this interstate system as the "Greek-Eastern system;" however, I now prefer to call it the "Graeco-Middle Eastern system" for better organization and clarity. Note Overtoom (2016a), 986-988, 992, 995, 997-998.

25 Note Eckstein (2006), Ch. 4; (2012).

26 In a previous article, I referred to this interstate system as the "new Eastern system;" however, I now prefer to call it the "Iranian system" for better organization and clarity. Note Overtoom (2016a), 985-987, 997-1001. 
After the emergence of the Iranian interstate system by the 230s, Parthia and Bactria no longer concerned themselves directly with the geopolitical developments and rivalries of the eastern Mediterranean, which remained the focus of the traditional Hellenistic Successor states until the rise of Roman unipolar hegemony over the entire Mediterranean from the $190 \mathrm{~s}-160 \mathrm{~s} .{ }^{27}$ Moreover, the geopolitical developments of the Iranian interstate system were only intermittently and indirectly related to those of the eastern Mediterranean interstate system through sporadic Seleucid efforts to reclaim their lost eastern lands in the 230s, 200s, 180s, 160s, 130s, and 120s.

Thus, the Seleucid Empire came to operate simultaneously in separate major interstate systems, which is a geopolitical distinction shared by several other large, powerful empires throughout history. ${ }^{28}$ A good illustration of this separation between the geopolitical developments in the west and those in the east is the fact that all of our surviving sources view events in Syria and Babylonia as separate from one another in this period. ${ }^{29}$ The geopolitical developments in the east, especially those concerning Parthia, had no direct connection to the emerging international environment of the Graeco-Roman Mediterranean world. They instead belonged to a separate interstate system in the east that was only indirectly affected by western developments.

The major difference between the participation of the Seleucids in the eastern Mediterranean interstate system and the Iranian interstate system was the political, cultural, and economic focus of the Seleucids. The Seleucids controlled one of the largest empires in the world in this period, establishing themselves as the imperial successors of Alexander and the Persians in the Middle East; however, they appear to have had a slightly different outlook on their hegemony in the east than their predecessors. Alexander and the Persians had viewed their imperial space as limitless on the central Asia steppe and in the Indian subcontinent; however, Kosmin recently has argued that the Seleucids formed stricter limitations on their imperial space, especially along their eastern frontier, with "explicit and formal recognition of equal peer kingdoms." ${ }^{30}$ Although, at least in theory, it is unlikely that the Seleucid kings abandoned their royal ideology of unlimited, universal rule, practical concerns in the west encouraged the Seleucids to develop a

27 Note Eckstein (2012); Overtoom (2016c), Chs. 1-3.

28 See Overtoom (2016a), $1011 \mathrm{n}$. 106. It is worth noting that the Seleucids in fact stood at the intersection of several smaller international systems as well, including the Levantine bipolar rivalry with the Ptolemies, the Asia Minor multipolar cluster before 188 BCE, the Caspian axis of petty kingdoms, and even a Red Sea nexus of cities and tribes. Note Kosmin (2013).

29 Note Grainger (2013), 179.

$30 \operatorname{Kosmin}$ (2014), 123. 
more restricted policy in the east. ${ }^{31}$ Therefore, Kosmin's arguments for the limitation of Seleucid hegemony in the east, where the Seleucids actually restricted and shrank the limits of their imperialism when they created an "ideological limes" along the frontier of the central Asian steppe and in 306/305 ceded the Indus River valley and Arachosia (modern southern Pakistan) to the Mauryan Emperor, Chandragupta, in exchange for 500 war elephants, generally appear sound. ${ }^{32}$ The Seleucids decided to establish Bactria (modern northern Afghanistan) as a bulwark to protect the eastern edge of their empire and turned their attention to the geopolitical developments of the eastern Mediterranean. ${ }^{33}$

Since the Seleucids came to favor western geopolitical developments and rivalries, their participation in the eastern Mediterranean interstate system was active, aggressive, and frequent. Meanwhile, their participation in the Iranian interstate system was reactive, inconsistent, and sporadic. ${ }^{34}$ Although the Seleucid state remained an important power in the east, possessing the potential strength to threaten the survival of Parthia and Bactria, the Parthians and Bactrians continually took advantage of the Seleucids' western distractions to maximize their regional security and power, adding to their own regional rivalry.

The newly formed Iranian interstate system paralleled those found in the Mediterranean. It was a harsh international environment with multiple militarized, bellicose, and aggressive polities. There was no enforceable international law, a lack of ameliorative diplomacy, and no way to understand the realities of power relations between states short of open conflict. ${ }^{35}$ The Parthians faced serious threats to their security and survival from Hellenistic kings, native Iranian dynasties, and central Asian tribes. The crisis of the 240s-230s weakened the Seleucid state and distracted the Seleucid kings, fracturing the eastern frontier; however, the potential power of the Seleucid state remained considerable. There would be six attempted campaigns to reconquer the lands of the east over the course of a century by five different Seleucid kings: Seleucus II, Antiochus III,

31 Strootman (2004) argues that "claims to unlimited power were central to Seleukid ideology, and conquest was a principal duty of the king" and that Seleucid kings had to balance royal ideology about universal hegemony against political pragmatism. Yet the western focus of the Seleucid state helped create a different, more distant approach to the geopolitics of the east for the Seleucids. 32 For the new Seleucid boundary with the steppe, see Kosmin (2014), 59-61. Compare Holt (1999), 28; Strootman (2014); (2019); Grainger (2014), Chs. 5, 8; Lerner (2015a), 307. For Seleucus I's arrangement with the Mauryans, see App. Syr. 9.55; Strabo 15.2.9. Antiochus III later made a similar agreement with the new regional king, Sophagasenos. Polyb. 11.34.11-12.

33 Holt (1988); (1999), 28-29; (2012a); Lerner (2016).

34 Note Kosmin (2013); Plischke (2014), 315-334; Grainger (2014); (2015); (2016).

35 For the absence of international law in the ancient world, see Aron (1973), 98-99; Eckstein (2006), 1, 12, 20-22, 32, 39; Grainger (2017b). 
Antiochus IV, Demetrius II, and Antiochus VII. This clearly demonstrates the strength of their resolve to contest the Parthians and reclaim their lost territories. Yet only one of those campaigns was successful. This chaotic and dangerous international environment helped influence the Parthians' policies as they struggled, first, to survive within the Iranian interstate system and, later, to expand and dominate that system.

The Parthians maintained their kingdom through bloodshed and compromise in the late third and early second centuries, just trying to survive in a dangerous and unforgiving environment where massacre, mass enslavement, or even total destruction were continual concerns. ${ }^{36}$ Yet by the middle second century an opportunity arose to maximize their security and power as another major crisis gripped the Hellenistic Middle East. Within a generation the international environment once again suddenly and drastically changed. The Parthians emerged as the true rival of the Seleucids, dominating many of the lands once held by the successors of Alexander and significantly altering the course of history in the east.

\section{The Crisis Begins}

By the 230s, Arsaces I, the first king of the Parthians, had forged a strong independent state in northeastern Iran, and when the Seleucid king, Seleucus II, invaded to reclaim these lost lands, the Parthians defeated him, strengthening their position and safeguarding the existence of the Parthian kingdom. ${ }^{37}$ The task of reestablishing Seleucid hegemony over the Iranian plateau next fell to Seleucus' son, Antiochus III, who conducted a grand campaign (210-205), reoccupying large sections of eastern Iran, western Afghanistan, and southern Pakistan and establishing Parthia, Bactria, and an Indian kingdom in the northern Indus River valley as subordinate allies (Polyb. 10.28.5-31.1-13, 11.34.9-12; Just. Epit. 41.5.7).

36 The Parthians were ruthless when necessary. For example, note their execution of the Greek population of Sirynx in the early 200s, their mass enslavement of thousands of Greek and Macedonian soldiers and their suppression of Seleucia and Babylonia in the early 120s, and their destruction of the Guti tribe in the early 110s. Polyb. 10.31.10-13; Just. Epit. 38.10.8, 42.1.4; Diod. Sic. 34/ 35.15; Sachs and Hunger (1996), no. -118A.

37 Just. Epit. 41.4.9-10, 41.5.1; Just. Epit. Prol. 35-6; Amm. Marc. 23.6.3; Jo. Mal. 8.198; Phot. Bibl. 58; Strabo 11.8.8; Ath. 5.38; Posid. 16 (F. H. G. III.258); App. Syr. 11.67; Joseph. AJ 13.186, 218-9; I Macc. 14.2-3; Diod. Sic. 33.28.1. Note Lerner (1999), 35, 37; Overtoom (2016a), 999-1000; (2016c), 106-136. Strootman (2011), (2015), (2016) suggests Seleucus successfully vassalized Parthia. However, there is no evidence that Arsaces served as Seleucus' vassal, and the sources are clear that Seleucus' eastern campaign was a failure. Just. Epit. 41.4.9-10-5.1; Amm. Marc. 23.6.3; Jo. Mal. 8.198; Ath. 5.38; Posid. 16 (F. H. G. III. 258). 
Unfortunately for the Seleucids, although Antiochus' eastern campaign had forced the kings of Parthia and Bactria to become his subordinate allies, the volatility of his new network of subordinate allied kingdoms presented subsequent Seleucid kings with a major challenge. Once Antiochus or one of his subordinate allies died, the previous arrangement had to be renewed diplomatically or by force. ${ }^{38}$ Few of Antiochus' successors shared his diplomatic influence or military capability, and the resilience and proficiency of the Parthians played a fundamental role in undermining the sustainability of Antiochus' model of loose imperialism over subordinate allied kingdoms in the east in the second century. ${ }^{39}$ Since the competence of the Seleucid king in many ways dictated the ability of the state to maintain its hegemony, without a strong and determined central leader, the Seleucid Empire faltered, especially in the east. Once new leaders emerged in Parthia and Bactria, there was little incentive to submit willingly to the Seleucids, and therefore, a new eastern campaign was necessary about once a generation to maintain or reestablish Seleucid hegemony in the east. ${ }^{40}$

Moreover, Antiochus III's defeat in his war against Rome (192-188) once again drastically reshaped the international environment. The Seleucids came to function within three distinct major interstate systems: The Roman-dominated Mediterranean interstate system, the Seleucid-dominated Iranian interstate system, and the emerging multipolar Near Eastern interstate system that stretched from Egypt to eastern Anatolia over to the Caucasus and Mesopotamia. This new Near Eastern interstate system featured the rivalry of the Seleucids and Ptolemies but also included the actions of numerous middling and minor states, including the Hasmonean Kingdom in Judaea, Cappadocia in southeastern Anatolia, Pontus in northeastern Anatolia, Armenia, and various Arab tribes.

38 Grainger (2013, 65-67; 2015, 70, 78-81, 190, 193-195; 2016, 1-2; 2017a, 36-40, 138; 2017b) has argued extensively that treaties made by Hellenistic kings traditionally were agreements between two men, not binding agreements between two states; yet even these treaties were easily broken with regularity without a strong central authority or the power of international law to enforce them. The Parthian kings appear to have followed a similar diplomatic policy. See Dąbrowa (2010); Schlude and Rubin (2017). For the concepts of diplomacy and international law in antiquity, see for instance Grant (1962), 262; Ziegler (1964); Campbell (1993); Bederman (2001); Sartre (2007), 619620, 624; Wiesehöfer (2007b); Eilers (2009); Grainger (2017b). Polybius was a major advocate for the pragmatic choices of states and statesmen in foreign relations; however, he also had a strong moral viewpoint that one should act nobly. See Eckstein (1995).

39 Strootman $(2011 ; 2015 ; 2016)$ associates the transition of Seleucid imperialism in the east with Seleucus II; however, he assumes Seleucus' eastern campaign was successful. Antiochus is a far more likely candidate.

40 Grainger (2015), 80-81; (2016), 1-2; (2017a), 38-39. 
Although in the 180s-170s the Seleucid Empire remained the leading power in the Iranian interstate system, numerous distractions in the west and a series of military and political setbacks provided the Parthians with many opportunities to regain and expand their former strength. ${ }^{41}$ By the 160 s, the Seleucids to the west of Parthia and the Bactrians to the east of Parthia faced mounting difficulties that helped create another power-transition crisis in the Hellenistic Middle East, and the Parthians, especially under the leadership of Mithridates I, once again emerged as the great beneficiaries of this crisis. It is clear the Seleucids recognized the importance of reinforcing their wavering hegemony throughout the Iranian plateau. In fact, Antiochus III died in 187 while preparing for a second eastern campaign. ${ }^{42}$ Then in early 165, Antiochus' youngest son, Antiochus IV, began his own abortive eastern expedition. ${ }^{43}$

Although Antiochus IV was in the middle of suppressing the Maccabean Revolt in Judaea, the Parthians' sudden and violent invasion of Hyrcania (modern northern Iran) in early 165 diverted Antiochus' attention. ${ }^{44}$ The fifth book of Maccabees (7.10-13) records,

And it was told to king Antiochus [IV] what Mattathias and his son Judas had done. News of this came also to the king of the Persians [that is, the king of the Parthians]; so that he [likely Phraates I] played false with Antiochus, departing from his friendship, following the example of Judas. Which giving Antiochus a great deal of uneasiness, he called to him one of his household officers named Lysias, a stout and brave man, and said to him, "I have now determined to go into the land of Persia [that is, Parthia] to make war; and I wish to leave behind me my son [Antiochus V] in my stead; and to take with me half of my army, and to leave the remainder with my son." 45

Meanwhile, Tacitus (Hist. 5.8) states, "King Antiochus [IV] endeavored to abolish Jewish superstition and to introduce Greek civilization; the war with the Parthians, however, prevented his improving this basest of peoples; for it was

41 Dąbrowa (1999 [2000]), 9. The Parthians expanded the mints they were using to produce coinage in this period. This could indicate limited territorial expansion. Assar (2004), 80-82; Sampson (2015), 44-45.

42 Diod. Sic. 28.3.1, 29.15.1; Strabo 16.1.18; Just. Epit. 32.2.1-2. Note Grainger (2015), 190-193; (2016), 1, 52-53.

43 Joseph. AJ 12.293. Note I Macc. 3.31-2, 6.1-5; II Macc. 1.12-16, 9.1-4; IV Macc. 18.5; V Macc. 3.3, 7.18, 8.1. For Antiochus IV, see Mittag (2006); Taylor (2013), Ch. 10; Grainger (2016), Chs. 1-2. For Antiochus' planned anabasis, see Habicht (1989), 351; Grainger (1997), 24-25; (2016), 32-35, 52-53; Assar (2005a), 39; Olbrycht (2010a), 231; Assar (2011), 116; Taylor (2013), 163; Coloru (2014); Martinez-Sève (2014); Plischke (2014), 291-295.

44 Just. Epit. 41.5.9; Isid. 7; Herod. 1.125; Strabo 11.7.1, 8.1, 8.8; Plin. NH 6.18.48, 31.134; Curt. 6.5.1121; Arr. Anab. 3.24.1-3. Note Assar (2006c), 89; Olbrycht (2010a), 230.

45 Cf. I Macc. 1-6. For a recent study of the Maccabean Revolt, see Grainger (2012). 
exactly at that time that Arsaces had revolted [desciverat]." These accounts illustrate that Antiochus left Judaea hastily to pursue a war against the Parthians in the east late in his reign. However, the exact context of Antiochus' eastern campaign is debated, and some scholars reject Tacitus' comment as an error because of his use of the name "Arsaces." Scholars, beginning with Moore, have accused Tacitus, first, of not knowing that Arsaces I seized Parthia in the middle of the third century and, second, of confusing the actions of Arsaces I here with the Maccabean Revolt. ${ }^{46}$ Yet there is good reason to reject such criticisms. Nothing about Tacitus' comment definitively connects this “Arsaces” to Arsaces I. In fact, the Romans knew that all Parthian kings regardless of their original name took the name Arsaces upon their ascension as a royal title, much like the Romans used the titles Caesar and Augustus. ${ }^{47}$ It is far more likely that Tacitus here simply refers to the reigning Parthian king by his regal name, Arsaces, and therefore, we must consider, first, who was the Parthian king in 165 and, second, what this man had done to gain the full attention of Antiochus IV (Just. Epit. 41.5.1-6; Strabo 15.1.36).

The traditional date for the accession of Mithridates I to the Parthian throne is ca. 171, which would mean Antiochus IV conducted his eastern campaign to challenge Mithridates' rising ambitions in the east; however, evidence that Mithridates became king in 171 is inconclusive. Instead, Assar recently has made a convincing argument to shift the beginning of Mithridates' reign forward to ca. 165/ 164 and to alter Phraates I's reign to ca. 168-165/164. ${ }^{48}$ Therefore, Mithridates' older brother, Phraates, could have been king when Antiochus began his eastern campaign. In fact, the passages from $V$ Maccabees and Tacitus provide further evidence for this new chronology. In $V$ Maccabees the Parthian king betrayed Antiochus' "friendship," and Tacitus claims the Parthians had "revolted." These depictions make far more sense if we associate them with Phraates instead of Mithridates. ${ }^{49}$

The passage in V Maccabees perhaps illustrates that, following the death of Antiochus III, Parthian kings, such as Arsaces II, Phriapatius, Arsaces IV, and Phraates I had renewed terms of friendship with Seleucus IV and Antiochus IV. ${ }^{50}$ Yet it is clear that the Parthians first acted aggressively against the interests of the

46 See Moore (1931 [2005]), 188-189; Marcus (1943), 153; Wellesley (1964), 284; Chilver and Townend (1985), 94. Note Assar (2005a), 39.

47 Just. Epit. 41.5.8; Amm. Marc. 23.6.5-6. Note Dąbrowa (2016).

48 Assar (2005a), 38-45; (2006c), 88-89; (2011), 116. Compare Assar (2004); (2006a); Wilson and Assar (2007), 24-25.

49 Assar (2005a), 39-40; (2006c), 88-89.

50 For Arsaces IV, see Assar (2005a), 38; (2006c), 88; (2006-2007). 
Seleucids after a long period of peace when Phraates I attacked the Mardians and began to reoccupy Hyrcania in early 165 (Just. Epit. 41.5.9). With the attack against Hyrcania taking place while the Seleucids were occupied in Judaea, Phraates' actions were perhaps even a deliberate exploitation of the Seleucids' overtaxed logistical load.

The sudden western expansion of Phraates I was a blatant violation of the status quo between the Parthians and Seleucids established by Antiochus III. ${ }^{51}$ Thus, Phraates drastically altered the relationship of the Parthians and Seleucids, not Mithridates I, finally casting off friendly relations and violently rebelling against Seleucid hegemony. The sudden belligerence and success of Phraates concerned Antiochus IV and demanded a rapid Seleucid response. With half of the Seleucid military, Antiochus undertook a major retaliatory campaign aimed to punish the Parthians and restore Seleucid hegemony over the east. ${ }^{52}$

Before Phraates I died in ca. 165/164 he named his younger brother, Mithridates I, his successor. To do this Phraates set aside several of his adult sons (Just. Epit. 41.5.9-10). It is possible that Phraates, fearing his rapidly declining health, left the kingdom in his brother's more capable hands to secure the positive momentum of the dynasty and state..$^{53}$ Certainly, Mithridates shared his brother's emphasis on aggressive foreign policy, and Phraates' decision proved critical as Mithridates built off the momentum of his brother to raise the Parthian state to new heights of power. ${ }^{54}$

In terms of International Relations theory, under the long reign of Mithridates I (ca. 165/164-132) the Parthian state began its transition from a limited revisionist state, looking primarily to maximize its security regionally, to an unlimited revisionist state, looking to replace the current makeup of the Iranian interstate system with its own hegemony. ${ }^{55}$ The Parthians became no longer satisfied with regional power and influence on the Iranian plateau, instead becoming increasingly determined to supplant the Seleucids as the leading power in the Hellenistic

51 Phraates' attack on the Mardians perhaps was part of a larger Parthian strategy to conquer Media, see Assar (2006c), 89; Olbrycht (2010a), 230.

52 For the argument that Antiochus also took his eastern campaign as an opportunity to subdue Armenia, Media, and Persis, see Shayegan (2011), 161-165.

53 Assar (2005a), 41; (2011), 116. Assar (2006c), 89 also puts forth the argument that the Parthian Council (noted in Strabo 11.9.3) might have elected Mithridates as king.

54 Olbrycht (2010a), 230.

55 Unlimited revisionist states, although more common in antiquity, are rare in world history. Eckstein (2006), 26. For the recently revised chronology of Mithridates' reign, see Assar (2005a), 41-45; (2006a); (2006c), 88-98; (2011), 117. Sherwin-White and Kuhrt (1993), 197 recognized a new "Parthian policy of conquest and expansion" that began to form in the $170 \mathrm{~s}$. 
Middle East. ${ }^{56}$ Mithridates' aggressive and capable leadership was at the center of this transition.

Antiochus III's anabasis (210-205) had devastated the Parthian kingdom. The aggression of the Seleucid state, the failures of the Parthian military, and the drastic reversal of Parthian fortunes at the end of the third century served as a warning to the Parthians about the potential threat of neighbors and the need to maximize state power. ${ }^{57}$ Justin states that the Parthians came to seek vengeance against Seleucid aggression (Epit. 42.1.1). Mithridates I looked not only to recover the lost lands of Arsaces I's kingdom, but also to establish Parthia as the leading power in the Iranian interstate system. This was a momentous period of Parthian history that demands further attention and consideration. ${ }^{58}$ Opportunity, motivation, and capability all aligned for the Parthians as Mithridates settled old scores against the Seleucid Empire through hegemonic war. Mithridates was a daring and gifted military leader, and like his brother, he wasted little time in capitalizing on the renewed strength of the Parthian military, completing the reconquest of Hyrcania. ${ }^{59}$

In 165 Antiochus IV recognized the renewed aggression of the Parthians as a serious threat and closely followed the example of his father, Antiochus III, in preparing his eastern campaign. First, he organized his large army, placed trusted officials in charge of his western lands, and protected the position of his young son, Antiochus V (App. Syr. 8.45; V Macc. 7.10-13; cf. I Macc. 3.27-37). Second, he secured his northern frontier by subduing Armenia (Diod. Sic. 31.17a; App. Syr. 8.45, 11.66; Porph. 38, 55-56). Finally, he sought out a great sum of money to support his eastern expedition.

In 187 Antiochus III had attempted to loot a temple in southwestern Iran to finance another eastern expedition; however, he died in the attempt. ${ }^{60}$ In need of

56 Just. Epit. 41.5.9-6.3, 6-9 emphasizes that Mithridates forged an empire that stretched from "Mount Caucasus [in the Hindu Kush] to the river Euphrates" through determined conquest.

57 For the importance of power-maximizing policy to state survival, see Huntington (1993), 68-83; Zakaria (1998), 29; Taliafero (2000), 128-129. For power-maximizing behavior in the ancient world, see Eckstein (2006), 12, 15, 18, 49-50, 52, 118, 143-144, 149, 162-163, 174, 176, 179, 234, 241-242, 268, 315; (2012), 7.

58 Mithridates' conquests in the east have gained only limited scholarly attention, see Tarn (1951), 222-223; Masson (1951); Daffinà (1967), 40-82; Mukherjee (1969); Wolski (1980); Schippmann (1980), 24; Olbrycht (1998a), 82-105; (2010a); Assar (2005a), 42; (2006c), 88-89; Dąbrowa (2006). 59 Just. Epit. 41.5.10, 6.9 calls Mithridates "a man of extraordinary ability" and argues that he was "not inferior in merit" to Arsaces I.

60 The Greek and Roman sources are highly critical of Antiochus III's actions, associating his villainy in attempting to sack the temple with his desperation to pay his debts to the Romans. Diod. Sic. 28.3.1, 29.15.1; Strabo 16.1.18; Just. Epit. 32.2.1-2; II Macc. 1.13-16. Yet Antiochus' outstanding 
money to finance his own major eastern expedition and perhaps motivated by a desire to avenge the violent death of his father, Antiochus IV also chose to attempt to plunder a temple in southwestern Iran (Polyb. 31.9; Joseph. AJ 12.354-9; App. Syr. 11.66; II Macc. 9.1-3; Porph. 56). His assault faced similar stiff resistance and ended in abysmal failure. Antiochus did not die in the attack like his father; however, his failure in southwestern Iran derailed his eastern expedition. He lacked the money and no longer had the men to attack the Parthians immediately. Although the cause is much debated in the sources, Antiochus suddenly died, likely from disease, near Gabae (modern Isfahan, Iran) in late 164 while trying to salvage his eastern campaign. ${ }^{61}$

With the sudden death of Antiochus IV in the east, the Seleucid throne passed to his nine-year-old son, Antiochus V, whose short reign (164-161) was dominated by conflict, political intrigue, and Roman influence (App. Syr. 8.46-47; Joseph. AJ 12.360-361). The boy's regent, Lysias, had far too many concerns in the west to follow up on Antiochus IV's plans to subdue the Parthians. Thus, the burgeoning Parthian state avoided a major invasion that likely would have severely jeopardized its newly reacquired independence, and this respite from Seleucid retaliation allowed Mithridates I to pursue his aggressive foreign policy and military operations throughout the Iranian plateau. The collapse of the Seleucid government after the unexpected death of Antiochus IV exactly fits the theory of "powertransition crisis," where one pillar of the interstate system suddenly weakens (while another expands in power).

Much like the power-transition crisis of the 240s-230s that followed the setbacks of Antiochus II's reign, the power-transition crisis of the 160s-130s provided the Parthians with an immense opportunity to expand their strength and standing drastically at the direct expense of the damaged and distracted Seleucid Empire. ${ }^{62}$

debt to the Romans was modest (1,000 talents annually for a term of twelve years), much of which his successors decided not to pay: App. Syr. 7.38-39. For example, the Romans forced Carthage to pay an indemnity of 10,000 talents after the Second Punic War. Note Hoyos (2003), 179. After ten years Carthage offered to repay the entire debt, which the Romans refused: Livy 36.4.5-9. Antiochus' empire was larger and wealthier than the diminished state of Carthage. For sacred plunder and the Seleucids, see Taylor (2014).

61 Polyb. 31.9 states Antiochus died in Persia from madness. Joseph. AJ 12.354-9 records that Antiochus died of anxiety and grief in Babylon. Cf. I Macc. 6.1-16; Porph. 56. App. Syr. 11.66 states Antiochus died of disease. Cf. II Macc. 9.5-28. See Dąbrowa (1999 [2000]), 9; Assar (2005a), 41-42. The Hellenistic King List and the Babylonian Astronomical Diaries record that word of Antiochus' death and his body travelled quickly to Mesopotamia, making it highly unlikely that Antiochus died in Babylon. Assar (2005a), 41 n. 79-80. Note Sachs and Wiseman (1954), 204, 208; Sachs and Hunger (1996), 18-19.

62 See Overtoom (2016a). 
Moreover, much like the rebellions of the Seleucid governors Andragoras in Parthia and Diodotus in Bactria during the power-transition crisis of the 240s230s, the power-transition crisis of the 160s-130s afforded satraps in Media (northwestern Iran), Elymais (southwestern Iran), Persis (southern Iran), and Characene (southern Mesopotamia) the opportunity to rebel. As the Seleucid Empire once again began to fragment, Mithridates I and his regime established Parthia as the undisputed power on the Iranian plateau and the leading rival of the Seleucids within the expanding Iranian interstate system.

\section{The crisis continues}

After becoming king in 175, Antiochus IV appointed his close friend Timarchus to the major command of viceroy over the Upper Satrapies (App. Syr. 8.45; Diod. Sic. 31.27a). While Antiochus fought the Ptolemies and Jews in the west, Timarchus was the chief official in charge of maintaining the strength and influence of the Seleucids in the east. From his headquarters in Media, Timarchus witnessed the sudden aggression of Phraates I as he attacked the Mardians and began to reoccupy Hyrcania. In fact, it is likely that Timarchus was the official who sent urgent word to Antiochus in Judaea, stressing the seriousness of the Parthian threat ( $V$ Macc. 7.10-13). As one of Antiochus' closest friends and most powerful advisers, Timarchus' warning would have carried considerable weight and helps explain Antiochus' swift response to the deteriorating situation in the east. Although Antiochus likely marched his army from Judaea through Syria, Armenia, Babylonia, Elymais and finally to Persis in southern Iran before his sudden death, he also appears to have included Media in his plans for attacking the Parthians and likely had been in communication with Timarchus during the campaign. ${ }^{63}$ Yet Antiochus' sudden death in 164 swiftly ended his plans of eastern conquest, left the Parthians unmolested, and isolated Timarchus.

With Antiochus IV dead, the boy king Antiochus V was not capable of maintaining his position or managing the kingdom. His father's advisors, Lysias, Philip, Timarchus, and Heracleides, and Antiochus V's twenty-two-year-old cousin Demetrius all vied for power and influence within the wavering empire. Much like Andragoras and Diodotus before him, without a strong central authority to help

63 Before dying Antiochus commanded one of his companions, Philip, to act as a guardian of Antiochus' young son. Philip was to deliver the regalia of the king to Antiochus V, and he was to return to Antiochus $\mathrm{V}$ the second half of the royal army that had accompanied Antiochus IV to the east. Philip's new command included royal forces stationed in Persia and Media. Jos. Ant. 12.360-1; IMacc. 6.55-56. 
protect the eastern lands of the empire and with mounting pressures threatening the security of his lands, Timarchus soon decided to declare independence in Media. Another series of civil wars threatened to fracture the Seleucid state.

In terms of International Relations theory, the sudden aggression of Parthia and the turmoil that followed the death of Antiochus IV caused another powertransition crisis in the Hellenistic Middle East. This crisis, which lasted from the late 160 s to the early 130s, facilitated extensive Parthian conquests, expanding the bounds of the Iranian interstate system and causing it to overlap with the lands of the Near Eastern interstate system for the first time. By the late 160s, the rapidly shifting geopolitical situation in the Hellenistic Middle East had helped foster a dangerous international environment of heightened uncertainty and anxiety between polities. ${ }^{64}$ For example, Justin (Epit. 41.6.1-3, 6-7) emphasizes the uncertainty of power relations between Parthia and Bactria in this period and the violence of the international environment, stressing the sudden and unexpected decline of Bactria under the pressures of "various wars" and the rise of Parthia "to the highest degree of power."

The sudden resurgence of the Parthians in the Iranian interstate system drastically altered power relations. Widespread conflict and rapid change facilitated and perpetuated the power-transition crisis of the 160s-130s as the hegemony of the Seleucids fractured temporarily into a multipolar system of numerous competing polities. ${ }^{65}$ The systemic pressures of the interstate anarchy within the Iranian interstate system (for example, heightened militarism, uncertain power capabilities, lack of security, fear of destruction) encouraged aggression and open con-

64 The dilemma, known as the "uncertainty principle," forces states to work continually to identify and counteract potential or perceived threats to their security through efforts to maximize power at the expense of the security of neighbors. Further, this opaque awareness of power capabilities throughout an interstate system forces states to consider and prepare for "worst-case scenarios." The security dilemma is a process whereby one state that successfully increases its security does so at the cost of the security of its neighbors. This in turn pushes those neighboring states toward further efforts to maximize their own power and to expand state security. For the uncertainty principle, worst-case scenario, and security dilemma, see Jervis (1976), 58-113; (1978), 167-214; Waltz (1988), 619; Liska (1990), 482; Sheehan (1996), 8; Glaser (1997), 177, 184; van Evera (1998), 13-14; Copeland (2000), 12, 17, 145-147, 165-168. For opacity of awareness between states and the potential for conflict, see Gilpin (1981), 9; Thompson (1988), 41; Waltz (1993), 73; Wohlforth (1994/1995), 104-105, 123, 127; Jervis (2001), 282 and n. 2. Eckstein (2006), 36 calls the ancient world one of the grimmest examples of international relations. For the impact of growing tension on eventual conflict, see Midlarsky (1988), 6, 20-44; Thompson (1988), 3-28.

65 For multipolarity, see Gochman and Maoz (1984), 592-593; Geller and Singer (1998), 128; Keeley (1999), 118-21; Eckstein (2006), 20, 23, 67. A system of unipolarity, wherein one state dominates the entire system, is generally the least war-prone. However, unipolarity is difficult to obtain and often unstable. Geller and Singer (1998), 115-117. 
flict between numerous states and statesmen during the crisis to eliminate potential threats and to establish a new, more reliable distribution of power throughout the Hellenistic Middle East. ${ }^{66}$ The hostile and unstable international environment of the Hellenistic Middle East during the power-transition crisis of the 160s-130s helped encourage the aggressive foreign policies of several leaders, including Mithridates I in Parthia and Timarchus in Media.

This chaotic environment provided Mithridates I with a great opportunity to implement aggressive foreign policy and expand his kingdom at the expense of the Parthians' rivals. The important frontier region of Bactria became Mithridates' first target. Continual dynastic conflicts and an ongoing rivalry with the IndoGreek Kingdom in northern India increasingly distracted the Bactrian kings and sapped the strength of their kingdom, gradually drawing the Bactrians' attention away from their precarious northern and western borders. ${ }^{67}$ During the crisis Bactria became increasingly vulnerable to nomadic and Parthian aggression in this chaotic environment.

Mithridates I conducted a successful war against Bactria by the middle 150s (and perhaps as early as 163/162). ${ }^{68}$ The Parthians conquered the western portions of Aria (western Afghanistan) and Margiana (eastern Turkmenistan) in this conflict, significantly expanding their eastern territory and raising their profile within the Hellenistic Middle East. ${ }^{69}$ Mithridates even implemented new imperial imagery on his coinage to signify his victory over the Bactrian Greeks. ${ }^{70}$ His victory

66 For the pressures states feel to seek power under a system of interstate anarchy, see Brecher and Wilkenfeld (1982), 380-417; Holsti (1991), 20; Geller and Singer (1998), 99; Keeley (1999), 160-161; Eckstein (2006), 1, 12, 20-22, 32, 39. In an effort to survive in an unforgiving and violent international environment, states often turn to grim self-help policies in an ongoing competition for limited resources. For self-preservation and "self-help" as a realist concept, see Aron (1973), 64-65, 130; Liska (1978), 4-6; Waltz (1979), 104; (1988), 616; Mearsheimer (1994-1995), 11-12; Sheehan (1996), 8.

67 Narain (1957); Bopearachchi (1991); Holt (1999), 135; Rtveladze (2011), 149-150; Grainger (2013), 71-76; Lerner (2015a), 309-311.

68 Strabo 11.9.2. For the controversy surrounding the dates of Mithridates' invasion of Bactria, see Olbrycht (2010a), 237; Lerner (2017), 11. Assar (2005a, 42; 2006c, 89) originally placed the war against Bactria in 163 after the sudden death of Antiochus IV, which seems appropriate. Yet he later oddly placed the campaign around 150 (Assar 2011, 117).

69 Mithridates annexed the Bactrian eparchies of Turiva and Aspionus: Strabo 11.9.2, 11.2. For the debated identity and location of these districts, see Assar (2006c), 89 n. 12; Olbrycht (2010a), 234236; Rtveladze (2011), 149-150; Lerner (2015b), 46, 48-52. For the uncertain date and scope of this campaign, see Tarn (1932), 579; Debevoise (1938), 19-20; Jenkins (1951), 15-17; Bivar (1983), 33; Sherwin-White and Kuhrt (1993), 84; Torday (1997), 350-351; Dąbrowa (2006), 38; Assar (2006a), 2; Olbrycht (2010a), 232-238; Lerner (2015b).

70 Lerner (2017). 
drastically shifted the power balance on the Iranian plateau in Parthia's favor, and Bactria never again emerged as a major actor in the geopolitics of this region.

Meanwhile, Timarchus, who had spent over a decade in Media consolidating his power and wealth, found himself in a vulnerable position with the sudden death of Antiochus IV. Timarchus had no ability to influence Antiochus' young son, Antiochus V, who was under the control of the royal advisor Lysias in Syria. When Antiochus V's cousin, Demetrius I, escaped from his captivity at Rome, executed Antiochus V and Lysias, and seized the Seleucid throne in 162/161, Timarchus was unable to intervene and unwilling to accept this usurper, declaring himself king in Media soon afterward. ${ }^{71}$ Timarchus quickly raised "an army of considerable size" and forged a military alliance against Demetrius with King Artaxias of Armenia, who had taken advantage of the crisis to reassert his independence (Diod. Sic. 31.27a).

Timarchus utilized his large army and new alliance to rapidly expand his territory outside of Media. Diodorus (31.27a) states, "Having, moreover, intimidated the neighboring peoples by an impressive display of force, and brought many of them under his sway, he marched against Zeugma [on the Euphrates], and eventually gained control of the kingdom.” Although Diodorus exaggerates Timarchus' success in the war against Demetrius I, Timarchus began to call himself "Great King" and possibly gained control of Media Atropatene and Elymais before occupying Babylonia in 161/160. ${ }^{72}$

Scholars continue to debate the actions of the Parthians during the Seleucid civil war. The crisis eventually encouraged the Parthians to invade Media; however, it is unclear if Mithridates I attacked Media before Timarchus marched west to fight Demetrius I. Recently, Olbrycht argued that Timarchus probably repulsed Parthian attacks in the late $160 \mathrm{~s}$, which allowed him to secure his eastern frontier before invading Babylonia. ${ }^{73}$ Meanwhile, Grainger suggests that Timarchus and Mithridates made an agreement that limited Parthian expansion westward. ${ }^{74} \mathrm{Fi}$ nally, Taylor claims that Timarchus "scored a major victory over the Parthians and used this victory to proclaim himself king." 75 Yet there simply is no evidence that directly links Timarchus to a conflict or a treaty with the Parthians.

71 See App. Syr. 8.45-7; Polyb. 31.11-15; I Macc. 7.1. Timarchus had many supporters at Rome. Diod. Sic. 31.27a states, "by launching many accusations against Demetrius, [Timarchus] persuaded the senate to enact the following decree concerning him: 'To Timarchus, because of ... to be their king.”' Thus, it appears the Romans supported Timarchus' bid for power.

72 Olbrycht (2010a), 232; Plischke (2017).

73 Olbrycht (2010a), 232.

74 Grainger (2013), 129-130.

75 Taylor (2013), 155. 
To connect Timarchus to the Parthians, scholars have cited a passage from Justin (Epit. 41.6.6-7), which states, "During the course of these proceedings among the Bactrians [that is, the Indian wars of Eucratides I], a war arose between the Parthians and Medes, and after fortune on each side had been some time fluctuating, victory at length fell to the Parthians. Mithridates [I], enforced with this addition to his power, appointed Bagasis over Media, while he himself marched into Hyrcania." "76 Justin here illustrates that there was a long struggle for Media; however, Justin plainly states that this conflict did not occur until Eucratides had invaded India, which most likely occurred after Mithridates' successful war against the Bactrians in the late 160 s or early 150 s. $^{77}$ Moreover, after invading Babylonia in 161, Timarchus' reign was short. Demetrius I occupied Babylonia and Media soon after his defeat of Timarchus in $160 .^{78}$ Therefore, the available window for a conflict between Timarchus and the Parthians is extremely small.

The evidence does not support Taylor's assertion that Timarchus decisively defeated the Parthians and used that victory to declare himself king. In fact, Diodorus (31.27a). demonstrates clearly that Timarchus declared himself king in direct opposition to the usurpation of Demetrius I. Meanwhile, Grainger's conclusion that Timarchus would not have been able to rebel in Media if the Parthians had been free to attack him ignores that Androgoras and Diodotus had done exactly that in the face of the aggression of the Parni under Arsaces I in the 240s. ${ }^{79}$ Instead, the collapse of Seleucid authority after Antiochus IV's death and the growing power of Mithridates I were the exact reasons for Timarchus' rebellion. Moreover, there also is little reason to accept Grainger's suggestion that Timarchus and Mithridates forged a treaty.

Timarchus had been the strong ally of Antiochus IV, who had threatened to conquer and punish the Parthians in 164. Yet Demetrius I's usurpation of Antiochus V's throne, encouraged Timarchus to declare his kingship and necessitated a civil war. Timarchus was hostile toward the Parthians; however, he could not afford to attack Parthia in 162/161 before dealing with Demetrius in the west. Meanwhile, Mithridates I had little reason to befriend the hostile Timarchus nor, more importantly, to limit his own western military ambitions willingly (Just. Epit. 41.6.6-9). A favorable treaty between Timarchus and Mithridates was plausible only after a decisive engagement, for which no evidence exists.

76 For the convincing argument that Bagasis (or Bacasis) was Mithridates' brother, see Assar (2005a), 48; (2006c), 89; (2011), 117; Olbrycht (2010a), 239; Shayegan (2001), 72-73.

77 Just. Epit. 41.6.4-5; Strabo 15.1.3. Note Jakobsson (2009); Olbrycht (2010a), 231-232.

78 Demetrius killed Timarchus in Babylon and gained the epithet Soter ("savior") from the Babylonians. App. Syr. 8.47; Diod. Sic. 31.27a; Just. Epit. Prol. 34.

79 Note Overtoom (2016a). 
Despite the assumptions of recent scholars, it seems highly unlikely that Timarchus clashed with the Parthians in the late 160s. If Timarchus declared himself king in 162/161, he would have needed time to organize his army, forge his alliance with Armenia, and consolidate his power over his immediate neighbors before invading Babylonia in 161/160. Meanwhile, Mithridates I was not ignorant of the considerable power Timarchus wielded in Media even after the death of Antiochus IV. Timarchus had spent over a decade strengthening the defenses of Media, and his diligent efforts of course help explain why it later took the Parthians so long to subdue the region. Diodorus (31.27a) records that Timarchus was one of the most powerful men in the Hellenistic Middle East in the late 160s, and he used this strong position to frighten and coerce his regional rivals. In fact, the Parthians likely were one of the neighboring peoples whom Timarchus intimidated with his impressive display of force early in his reign.

In the late 160 s the Parthians remained a minor power just beginning to reemerge from decades of recovery. ${ }^{80}$ After consolidating the recent territorial gains of his brother, Mithridates I readied for the defense of Hyrcania and Parthia in 165/164. ${ }^{81}$ The failure of Antiochus IV's eastern campaign saved Parthia from invasion; however, Timarchus' position in Media remained strong. Mithridates simply did not have the resources in 163/162 to invade Media, and the unraveling crisis within the Seleucid Empire encouraged Timarchus to remain cautious in Media. $^{82}$

Timarchus and Mithridates I found themselves in a stalemate. Neither leader could hope to overwhelm the other without first securing more resources, so they turned their attentions to other targets. Timarchus became involved in the Seleucid civil war in the west, and Mithridates quickly turned his attention to the vulnerable frontier of Bactria. By the time Mithridates completed his war against Eucratides I and occupied large sections of Aria and Margiana, he did not have time to organize and conduct major operations against Media before Timarchus' occupation of Babylonia in 161 and his death in 160. Thus, the long and difficult campaign of Mithridates to conquer Media most likely did not occur until the $150 \mathrm{~s}$.

80 Karras-Klapproth (1988), 152-153; Assar (2004); (2005a); (2011), 115-116; Taylor (2013), 77; Grainger (2015), 68-69.

81 The Parthians had begun to expand west of the Caspian Gates at this time. Note Olbrycht (2010a), 239.

82 Diod. Sic. 31.27a states that Timarchus' power was intimidating and unrivaled in the region. It had taken the Parthians years to defeat the much smaller Mardians in Hyrcania: Just. Epit. 41.5.9. 


\section{The Parthian conquest of Media}

Even though Timarchus and Mithridates I did not go to war in the late 160s, large-scale conflict between the Parthians and Seleucids became increasingly likely as the Hellenistic Middle East descended into the power-transition crisis of the 160s-130s. Conflict had already emerged in Media, Babylonia, Aria, and Margiana, and rebellions in Elymais and Persis destabilized the region further. ${ }^{83}$ The eastern lands of the Seleucid Empire became increasingly vulnerable to the rising power of the Parthians, and the renewed aggression of the Parthians on the Iranian plateau demanded Seleucid retaliation. It was in this period that a new phase of hegemonic warfare between the Parthians and Seleucids began to determine the new balance of power in the Iranian interstate system as the Parthians gradually strove to replace Seleucid hegemony and dominate the Hellenistic Middle East. ${ }^{84}$

By the end of the 160 s, the Parthians controlled Parthia, Hyrcania, Aria, and Margiana, adding significantly to their logistical and financial capabilities. With new resources and a stronger eastern frontier, Mithridates I was in a better position to challenge the Seleucids in the west. Western expansion into Media, Persia, and Mesopotamia offered major political and financial incentives for the Parthians; however, the conquest and occupation of these regions proved immensely difficult as the Seleucids and regional dynasts challenged Parthia's rising hegemony frequently.

With the defeat of Timarchus in 160, Demetrius I regained control of Babylonia and Media, restoring the integrity of the empire at least temporarily. Demetrius' success in this civil war led Grainger to suggest recently that Mithridates I waited ten years to attack Media after Timarchus' defeat because "the Seleukid state under Demetrios I was strong enough to deter any adventure by the Parthian King." ${ }^{85}$ However, this stance is too dismissive of the evidence and exaggerates Demetrius' position in the 150 s. Although Demetrius was able to overcome Timarchus, his control over the empire was fragile and western concerns dominated his attention.

Demetrius I had poor relations with the Romans after his escape from captivity, which his success in seizing power in Syria did not alleviate (App. Syr. 8.45-

83 Diod. Sic. 31.27a; Strabo 11.9.2. Note Le Rider (1965), 347; Harmatta (1981), 189-217; Assar (2005a), 42; (2006c), 89; Olbrycht (2010a), 232-237; Shayegan (2011), 155-176; Grainger (2013), 130-131, 136-137; Plischke (2017); Lerner (2017), 11.

84 The aggression of Arsaces I and of Phraates I had been limited to regional objectives for regional power and security. Overtoom (2016a). Note Just. Epit. 41.4.6-9, 5.1-5, 9-10.

85 Grainger (2013), 130. 
47; Polyb. 31.11-15; I Macc. 7.1). In 160 Demetrius placed generals in charge of the defense of his eastern satrapies and immediately returned to the west, where he sent considerable gifts to the Romans to appease their anger. ${ }^{86}$ Yet the gifts did little to satisfy the Romans, and when Demetrius attempted to intervene in Cappadocia (southeastern Anatolia) in 159, the Romans quickly overruled his decision. ${ }^{87}$ Justin (Epit. 35.1.1) states, "Demetrius, having possessed himself of the throne of Syria, and thinking that peace might be dangerous in the unsettled state of his affairs, resolved to enlarge the borders of his kingdom, and increase his power, by making war upon his neighbors." Justin illustrates that Demetrius recognized his vulnerable position, and it is not surprising that he chose to act aggressively to expand his security and power against a weak neighboring state. Yet Demetrius was unable to invade Cappadocia or to install a puppet ruler because of the severe limitations of his power and influence within the Roman-dominated Mediterranean interstate system. ${ }^{88}$ The Romans' decision to protect Cappadocia was meant to reassert their hegemony at the direct expense of Demetrius' regime, and the situation in Cappadocia was an embarrassment for Demetrius that called into question his strength and legitimacy, severely limiting his effectiveness in the 150 s.

After the fiasco in Cappadocia, the capital city of Antioch rebelled against Demetrius' rule, eventually leading to Alexander Balas openly challenging Demetrius for the Seleucid throne in $152 .{ }^{89}$ Despite the weak claim to the throne of Alexander, Demetrius continued to mismanage his affairs, and Alexander eventually gained the support of the Jews and Ptolemaic Egypt in the civil war (I Macc. 10.1, 21, 46-47, 51-58; App. Syr. 11.67). Demetrius was unable to repeat his success against Timarchus and died in battle against Alexander in 150 (Just. Epit. 35.1.92.2; I Macc. 10.48-50; Joseph. AJ 13.116-119).

Thus, Demetrius I spent his entire tumultuous reign (162-150) suppressing revolts, fighting rivals to his throne, and trying to reconsolidate the power of the empire. He had every reason and desire to act aggressively against neighboring states, which included Parthia; however, he lacked the capability to do so. Jus-

86 Demetrius sent a crown valued at 10,000 pieces of gold and offered to turn over the man who had murdered the Roman ambassador, Octavius, in Syria. App. Syr. 8.47; Diod. Sic. 31.29-30.

87 Demetrius wanted to replace King Ariarathes V with the king's brother, Orophernes II, in exchange for a payment of 1000 talents; however, the Romans determined both brothers should reign together. App. Syr. 8.47; Just. Epit. 35.1.1-2; Polyb. 32.10, 33.6; Diod. Sic. 31.31-32b.

88 Note Eckstein (2006), Ch. 6; (2012), Ch. 9.

89 Just. Epit. 35.1.3-11. Timarchus' brother, Heracleides, aided Alexander in his bid for power, as did King Attalus II of Pergamum. Polyb. 33.15.1; Diod. Sic. 31.32a. 
tin tells us that Mithridates I's conquest of Media was a long affair with multiple setbacks, and Moses of Chorene indicates that Mithridates fought the generals of Demetrius in Media during this struggle. ${ }^{90}$ Demetrius was never strong enough to "deter" the Parthians from attacking Media. In fact, his ineffectiveness and vulnerability encouraged the Parthians to attack his isolated generals in the east.

Grainger's recent conclusions, first, that Mithridates I did not attack Media until after Alexander Balas became king in 150 to avoid Demetrius I's power, second, that Mithridates justified his attack against Alexander because he was a Seleucid usurper, and, third, that Mithridates hoped to revive Achaemenid legitimacy under the Arsacid dynasty are not tenable. ${ }^{91}$ There simply is no convincing evidence to support such conclusions. Demetrius' regime was vulnerable, the Arsacids were not yet concerned with the dynastic politics of the Seleucids, and the Parthians' interest in an Achaemenid revival for their imperial propaganda arguably did not develop until their much later conflict with imperial Rome. ${ }^{92}$ Instead, Mithridates began his campaign to conquer Media and Media Atropatene as early as 158 and no later than $155 .{ }^{93}$ Mithridates did not need to justify his aggression against the Seleucids in Media along strong ideological or propagandistic lines; rather, he had far more compelling practical concerns, such as the expansion of his power against a vulnerable rival.

Although the western affairs of the empire during the crisis demanded Demetrius I's attention, the Parthians found the conquest of Media slow and difficult because of a determined resistance by various Seleucid generals made possible in part by the prior efforts of Timarchus to establish the region as a military stronghold. Mithridates I likely subjugated Media Atropatene as a tributary kingdom in the north; however, the strong defensive positions of the Seleucids in the south and their successful counterattacks turned the campaign into a war of attrition. ${ }^{94}$ An unfinished Greek-Aramaic inscription on a carving of Heracles Triumphant at the Bisitun Pass in what is western Iran today, dated 148, gives us a good indication of the back and forth Seleucid and Parthian contest during the

90 Just. Epit. 41.6.6; Moses 2.2. Note Assar (2005a), 42.

91 Grainger (2013), 130, 136; (2016), 68-70, 77-78. Grainger here follows the rather dismissive and inadequate "unit-attribute" explanation that Parthian success stemmed from their eager "restoration" of the image of the Achaemenid Persian Empire championed by Wolski (1966; 1976; 1983; 1985; 1993).

92 Shayegan (2011), 244, 330-331; Overtoom (2016b); (2017a).

93 Note Assar (2006c), 89; Olbrycht (2010a), 238-240. Demetrius' failure in Cappadocia perhaps helped encourage Mithridates to act aggressively.

94 Assar (2006c), 142 n. 172; Olbrycht (2010a), 239-240. 
long conquest of Media. ${ }^{95}$ The inscription asks for the safety of Cleomenes, the Seleucid viceroy of the Upper Satrapies in Media at the time. ${ }^{96}$ The association of the inscription with Heracles Triumphant perhaps indicates that Cleomenes had won a victory against the Parthians as late as 148 , signifying one of the many reversals of the Parthians' fortunes during this conflict mentioned by Justin. ${ }^{97}$ The inscription also illustrates that the Seleucids still occupied parts of Media in 148 and that the permanent Parthian conquest of the region was not complete until after this date. ${ }^{98}$ Mithridates marked his final annexation of Media by making his brother the new satrap of the region in ca. 147 and by issuing a series of commemorative coins. ${ }^{99}$

\section{The crisis expands}

The continued aggression of the Parthians and an ongoing series of Seleucid civil wars perpetuated the power-transition crisis of the 160s-130s in the Hellenistic Middle East. Although Alexander Balas killed Demetrius I in battle in 150, his rule similarly was vulnerable and dominated by western concerns (Just. Epit. 35.1.92.2; I Macc. 10.48-50; Joseph. AJ 13.116-119.). Alexander had been a usurper of questionable lineage, and his efforts to gain legitimacy through a marriage alliance with Ptolemaic Egypt ultimately failed (I Macc. 10.51-8; Diod. Sic. 32.9c). Further, his generals in the east, although they continued to frustrate Mithridates I's advances in Media, were unable to eliminate the threat of the Parthians to the eastern lands of the empire. ${ }^{100}$ In 147 , as Media finally fell to the Parthians, Deme-

95 For recent evaluations of the political and propagandistic value of this carving and several other ancient Iranian rock reliefs, see Canepa (2014); (2015).

96 Robert (1963), 76; (1967), 283, 291; Bivar (1983), 33.

97 See Grainger (2013), 130; Callieri and Chaverdi (2013), 693.

98 Assar (2005a), 42. For the argument that the Seleucids had lost eastern Media to the Parthians by 148 BCE, see Le Rider (1965), 338ff; Schippman (1980), 24; Bivar (1983), 33; Frye (1984), 210; Olbrycht (2010a), 238; Assar (2011), 117.

99 Just. Epit. 41.6.7; Moses 1.8, 2.68. See Daryaee (2015), 286. A Median nobleman perhaps married his daughter Rinnu to Mithridates after the Parthians had expelled the Seleucids from the region. The Parthians controlled all of Media no later than 145. Assar (2005a), 42-43. Mithridates issued a series of silver obols (S12.4-5) and copper coins (S12.13, S12.17-18, and S12.23-24) in Ecbatana. Assar (2006c), 89-90. For monetary production in Media under the Parthians, note Boillet (2016). For an introduction to the cultural developments in Media under the Seleucids and Parthians, see Callieri and Chaverdi (2013), 691-695.

100 Cleomenes, the Seleucid general who left the inscription to Heracles Triumphant at the Bisitun Pass in 148, would have been a trusted general of Alexander. Note Canepa (2014); (2015). 
trius' eldest son, Demetrius II, arrived in Syria with the support of Ptolemy VI to contest Alexander's throne, and the Seleucid Empire again descended into civil war. ${ }^{101}$

In 145, Demetrius II and Ptolemy VI defeated Alexander Balas decisively in battle and secured his assassination. ${ }^{102}$ Yet although Demetrius won the war, Media was lost, and he had to hand over control of Coele Syria to Ptolemaic Egypt in exchange for Ptolemy's military support and a marriage to his daughter, Cleopatra Thea. Further, dynastic strife, ineffective administration, and poor military leadership plagued Demetrius' regime. ${ }^{103}$ Demetrius quickly found that the growing factionalism of the Seleucid state presented him with numerous potential rivals and several unhappy communities. Widespread unrest in Syria encouraged the general Diodotus Tryphon to make a bid for power as the guardian of Alexander's young son, Antiochus VI, and the Seleucid Empire descended into an even longer, more difficult civil war from $145-138 .{ }^{104}$

The power, prestige, and influence of the Seleucids was in jeopardy, and to make matters worse, Rome, Ptolemaic Egypt, and Parthia were not the only concerns of the Seleucids during the crisis. In the 160s, Elymais and Persis in southern Iran appear to have followed the examples of Parthia, Bactria, and Media, asserting their local autonomy and briefly breaking away from the Seleucid Empire. ${ }^{105}$ Then in the 140 s the mounting troubles of the Seleucid state allowed Elymais and Persis to assert their independence once again. ${ }^{106}$ Meanwhile, Char-

101 I Macc. 10.67-68, 11.1-12; Jos. Ant. 13.116-119; Diod. Sic. 32.9c-d. Note Grainger (2013), Ch. 7; (2016), Ch. 5.

102 I Macc. 11.14-17; Jos. Ant. 13.116-119; Diod. Sic. 32.9c-d, 10.1; Just. Epit. 35.2.2-4.

103 Just. Epit. 36.1.1 calls Demetrius spoiled and lazy. Diod. Sic. 33.4, 4a, 9 also calls him cruel and hated.

104 Note Grainger (2016), Ch. 6. Tryphon proclaimed himself king in early 140, killing Antiochus VI soon after. See I Macc. 11.39-40, 54-56, 12.39, 13.31-32; Diod. Sic. 33.4a, 28, 28a; App. Syr. 11.68; Just. Epit. 36.1.7; Oros. 5.4.18. For another tradition that maintains that Antiochus VI died of illness due to surgery, see Jos. Ant. 13.218; Livy Epit. 55.11. This likely was propaganda from Tryphon's camp to remove the taint of regicide. Tryphon perhaps did not kill Antiochus VI until the middle of 138. Shayegan (2003 [2007]), 88-90. Antiochus VI was at least alive until early 140, see Sachs and Hunger (1996), no. 143A.

105 Shayegan (2011), 155-176; Grainger (2013), 130-131, 136-137. It is possible that Persis ruled itself autonomously throughout much of the first half of the second century. Persis intermittently dominated the region of the Persian Gulf, briefly occupying Characene and conducting a mass killing of 3,000 Greeks. See Callieri (1998); (2003); (2007), 115-146; Wiesehöfer (2007a); (2011); (2012); (2013); Curtis (2010); Olbrycht (2010a), 229-30; Shayegan (2011), 155-165, 168-187; Callieri and Chaverdi (2013), 691; Rezakhani (2013), 775; Grainger (2015), 76; Strootman (2017).

106 For recent accounts of the history of Elymais in this period, see Assar (2004-2005), 27-91; Dąbrowa (2005); Shayegan (2011), 62, 65-67, 77-83, 85, 88-104, 107-108, 114, 116-118, 122, 131, 
acene, which controlled the Euphrates and Tigris delta, also actively began asserting its autonomy in this period (ca. 141). ${ }^{107}$ Moreover, the vulnerability of the Seleucid state encouraged Arab raids to begin penetrating the southern frontier. $^{108}$

Yet the Parthians had emerged suddenly as the most pressing threat to the survival of the Seleucid state. The decline of Seleucid hegemony and the rapid rise of conflict throughout the Hellenistic Middle East during the crisis created a power vacuum that the Parthians eagerly began to fill. Mithridates I's conquest of Media, although difficult, and his control over the passes of the Zagros Mountains were crucial to further Parthian expansion to the west and south. Moreover, control of Media also gave the Parthians direct access to the important breeding grounds of the famous Nisaean horses of the Medes. ${ }^{109}$ The Parthian military increasingly required large numbers of quality horses and, although there is no evidence to suggest that the Parthians targeted this region strictly to gain access to this resource, control of these breeding grounds would have strengthened their army. ${ }^{110}$ Media quickly became a center of Parthian power and wealth, and as the crisis continued to unfold, Mithridates began to target the wealthy, urbanized, and vulnerable lands of Mesopotamia in the late 140 s. $^{111}$

\section{The Parthians' difficult western frontier}

Unfortunately, our sources for this period of Mithridates I's reign are vague and often at odds in the reconstruction of events. Justin (Epit. 41.6.7-8) records that Mithridates returned to Hyrcania after finalizing his conquest of Media, later returning to the west to conquer Elymais and then Mesopotamia. Yet a fragment of the Babylonian Astronomical Diaries states that Mithridates conquered Babylonia

156, 164, 183-187, 204-205, 207, 324-325; Rezakhani (2013), 772-774; Plischke (2014), 287-290. For Persis, see Shayegan (2011), 155-159, 161, 168-182; Rezakhani (2013), 775-777.

107 For Characene, see Schuol (2000); Wiesehöfer (2007a); Hansman (2011); Gregoratti (2011); Shayegan (2011), 82-85, 101, 110-116, 114, 120, 152, 156-157, 160-161, 165-168, 171, 176-177, 183186. For the Arabs, see Shayegan (2011), 120, 205-206.

108 Sachs and Hunger (1996), no. -145. Note Grainger (2013), 80.

109 Assar (2006c), 120. The Parthian military likely used a mixture of Akhal-Teke and Nisaean horses; however, they increasingly favored Nisaean mounts for their speed, strength, and beauty. For the Parthians' breeding of horses, see Shahbazi (1987); Olbrycht (2001).

110 Note Overtoom (2017b).

111 Assar (2006c), 89; Olbrycht (2010a), 230, 238-240; Shayegan (2011), 74; Callieri and Chaverdi (2013), 691-695; Boillet (2016). 
by the summer of 141 and then returned to Hyrcania, before marching to conquer Elymais. ${ }^{112}$

The difficult Parthian conquest and occupation of Media was complete by the end of 147; however, consolidating Parthian control over the region took several more years to accomplish. While Mithridates I and his brother, Bagasis, began the challenging work of strengthening Parthia's new western frontier, Mithridates had to monitor developments in the east closely (Just. Epit. 41.6.67). Mithridates likely returned to the east in 145 in response to two new threats. First, the Bactrian king Eucratides I died in 145 at the hands of his son. ${ }^{113}$ Therefore, Mithridates needed to return east to make sure that the new king of Bactria (there were three possible competing candidates: Heliocles I, Eucratides II, and Platon) had no intentions to act aggressively toward him. ${ }^{114}$ Second, and more importantly, the kingdom of Bactria was beginning to crumble under the mounting pressures of the invasions of the nomadic Saka and Yuezhi. ${ }^{115}$ In particular the wealthy and prosperous northern city Ai Khanoum likely fell to these invaders in ca. 146/145. ${ }^{116}$ Bactria had always been a key bulwark against the tribal confederations of this region; however, as the Bactrians sapped their strength with dynastic conflicts and wars in India, and as the violent displacement of the Yuezhi initiated a widespread migratory period for both them and the Saka toward Sogdiana (modern southern Kazakhstan, eastern Uzbekistan, Kyrgyzstan, and Tajikistan), the Bactrians increasingly were unable to defend their northern and eastern frontiers. ${ }^{117}$ With Eucratides I dead and his kingdom rapidly deteriorating, Mithridates could not ignore the growing vulnerability of Parthia's eastern frontier. Since becoming king in 165/164, Mithridates had quadrupled the size of the Parthian state and had made Parthia the leading power on the Iranian plateau; however, the Parthians' hegemony in the east remained vulnerable. From 147-141 Mithridates worked diligently to consolidate and secure the expanded frontiers of the Parthian state, also perhaps sub-

112 See Sachs and Hunger (1996), no. -140A, no. -140C. Note Shayegan (2003 [2007]), 84; Dąbrowa (2005); (2014), 61-63; Assar (2006c), 93; (2011), 117; Olbrycht (2017), 10. For an introduction to cultural developments in Elymais under the Seleucids and Parthians, see Callieri and Chaverdi (2013), 695-698.

113 Just. Epit. 41.6.5. Note Holt (2012b); Lerner (2015b), 52; (2017), 11.

114 Heliocles perhaps is the most likely candidate. Lerner (2015b), 48.

115 Olbrycht (2012); Grainger (2013), 137, 170; Lerner (2015a), 311-313.

116 Holt (1999), 25 et passim; Holt (2012b). Contra Lerner (2010), 69-72; (2011).

117 See Mair (2014), 8-15, 23-26, 29, 90, 144, 161-163; Daryaee (2015), 288. For recent reconstructions of Yuezhi history, see Benjamin (2007); Bivar (2009); Rtveladze (2011), 150; Olbrycht (2012); Lerner (2015a), 311-318. For the Saka, see Callieri (2016). 
duing tribes in southeastern Iran and southwestern Pakistan while he was in the east. $^{118}$

Mithridates I's continued efforts to strengthen and protect his eastern frontier were successful, at least temporarily; however, the wealthy lands of Mesopotamia, Elymais, and Persis remained tempting targets along the Parthians' extensive western frontier. In 141 Mithridates decided to risk the stability of his eastern frontier to strike at the heart of the Seleucid Empire. Late that spring he invaded and occupied Babylonia, which the Seleucids had mostly abandoned during the ongoing civil war between Demetrius II and Diodotus Tryphon in Syria, and Mithridates entered the symbolically powerful cities of Seleucia and Babylon as a triumphant conqueror, appointing governors of Macedonian descent to maximize support in the region. ${ }^{119}$

It is also likely that Persis fell under Parthian control at this time. ${ }^{120}$ Mithridates I's strategy could have been to organize his forces in Media, perhaps near Ecbatana, and then to strike rapidly in a two-pronged expedition. He clearly led the main Parthian force to conquer Babylonia; however, a trusted general, perhaps Bagasis, seemingly subdued Persis. These conquests expanded the bounds of the Iranian interstate system further west across the vast lands of Mesopotamia, which had been a part of the separate Near Eastern interstate system since the 180 s, creating for the first time what international relations theorist call "system overlap" between the separate Iranian and Near Eastern interstate systems. ${ }^{121}$ Although the Seleucids continued to contest Parthian hegemony in Mesopotamia for decades, these lands were now firmly established within the bounds of the expanding Iranian interstate system, and they were another significant step in the rapid growth of Parthia as an unlimited revisionist state within that interstate system.

118 Note Oros. 5.4.16; Diod. Sic. 33.18; Strabo 15.2.11. Oros. 5.4.18 claims that Mithridates' kingdom stretched from the Hydaspes River in Media to the Indus River. Note Verg. G 4.211. For the argument that the Parthian Kingdom eventually reached the mouth of the Indus River in Sind, see Daffinà (1967), 41-43. For Bagasis in Media, note Shayegan (2011), 74.

119 Mithridates appointed Antiochus, son of King Ar'abuzana, as his commander with Nikanor serving as one of Antiochus' subordinates. Sachs and Hunger (1996), no. -140A; Shayegan (2003 [2007]), 84; Sartre (2005), 25; Assar (2005a), 43-44; (2006c), 90-91; Olbrycht (2010a), 240; Grainger (2016), 82-83. Note Oros. 5.4.16; Moses 2.2.

120 Wiesehöfer (1994), 113, 118, 129; Wiesehöfer (2007a), 44-45; (2013); Shayegan (2011), 169; Strootman (2017). Note Pliny NH 6.28.111; Strabo 15.3.3, 24. For an introduction to cultural developments in Persis under the Seleucids and Parthians, see Callieri and Chaverdi (2013), 698-709.

121 For the expansion and merger of interstate systems, see Aron (1973), 87-88; Buzan, Jones, and Little (1993), 66-80; Eckstein (2006), 116. 
The campaign in 141 was Mithridates I's most aggressive and direct challenge to the deteriorating hegemony of the Seleucid Empire in the Hellenistic Middle East. The Parthians' control of the royal capital of Seleucus I was a glaring representation of their new position of power. In fact, control of Media, Persis, and Babylonia made Parthia far more than just a regional power, and the occupation of Babylonia's great cities in particular provided the Parthians with great prestige and immense wealth. ${ }^{122}$ Mithridates immediately struck a new series of silver tetradrachms (S13.1-2) in Seleucia on the Tigris, in which he adopted the epithet "Admirer of the Greeks," to commemorate his victory and appease the large Greek and Macedonian population in the area. ${ }^{123}$

With their conquests of Babylonia and Persis, which had been the administrative centers of the Achaemenids, Alexander the Great, and Seleucus I, the Parthians for the first time could claim to be the hegemonic rivals of the Seleucids. Moreover, the power-transition crisis of the 160s-130s had provided Mithridates with an immense opportunity to transform Parthia from a minor kingdom into an imperial power. The success of the Parthians and the threat they posed to the Seleucids assured further conflict between the two powers. The Seleucids could not let the aggression of the Parthians and, in particular, the loss of Babylonia, go unanswered, and the Parthians, who continued to expand westward for another half-century, had no intentions to limit their western ambitions to this region as the rising hegemon in the Iranian interstate system and as a newly formed unlimited revisionist state. ${ }^{124}$

Although further major conflict between the two leading powers of the Hellenistic Middle East was on the horizon, the Seleucids and Parthians had several other concerns threatening their security in this period. After the occupation of Babylonia in 141, the Babylonian Astronomical Diaries record that Mithridates I again abruptly returned to the east. ${ }^{125}$ Mithridates' immediate return to the Iranian plateau helps illustrate that, first, the conquests of Babylonia and Persis in 141 had been aggressive and opportunistic and, second, the eastern frontier continued to be in jeopardy. Assar, utilizing a passage from Strabo, even suggests that Mithridates returned to the east at this time to counter steppe invaders. ${ }^{126}$ Although we have no definitive evidence of military encounters between the

122 Boiy (2004).

123 Assar (2006c), 91.

124 Just. Epit. 38.3.1, 41.6.8-42.1.1, 2.3-6; Strabo 11.14.15, 14.5.2; App. Syr. 8.48; Jos. Ant. 13.369371, 384-386.

125 Sachs and Hunger (1996), no. -140C.

126 Assar (2005a), 43; (2006c), 91. Note Strabo 11.9.2. Although he is right to reject Tarn's argument that Mithridates returned to Hyrcania to invade Bactria, Jenkins' (1951), 15-16 assumption 
Parthians and the Saka at this time, Mithridates understood the considerable threat of the encroaching nomadic warriors and believed that his eastern lands were vulnerable. ${ }^{127}$

Mithridates I's decision to return to the east also illustrates that he did not anticipate the immediate challenges the Parthians faced to their occupation of Babylonia. The Babylonian Astronomical Diaries record that almost immediately following his departure from the region the recently independent people of Elymais from southwestern Iran invaded and began ravaging the territory, forcing Mithridates to return. ${ }^{128}$ The Elymaeans even burned Apamea on the Tigris before Mithridates and his generals counterattacked toward their capital, Susa. ${ }^{129}$

The power-transition crisis of the 160s-130s threw Mesopotamia into chaos with the region changing hands on no less than eleven occasions in this period (Timarchus in 161-160, Demetrius I in 160, Alexander Balas ca. 150, Demetrius II ca. 145, the Parthians in 141, the Elymaeans in 141/140, the Parthians in 140; Demetrius II in 139/138, the Parthians in 138, the Elymaeans in 138/137, and the Parthians in 137). ${ }^{130}$ Rebellions, raids, and a series of invasions destabilized and devastated the region, creating opportunity and incentive for further violence. The Parthians recognized the troubled state of Babylonia and the surrounding territories, conducting aggressive conquests. ${ }^{131}$

Even though his chronology of events is confused, Justin records that Mithridates I defeated the Elymaeans and conquered Elymais. ${ }^{132}$ Yet the Parthians' conquest of Elymais also was quite complicated. While the Parthians attempted to counter the advances of the Elymaeans, it is possible that the Seleucid usurper, Diodotus Tryphon, tried unsuccessfully to reestablish Seleucid control over Babylonia in $140 .{ }^{133}$ Moreover, although Mithridates seized Susa and issued a series of

that Mithridates was doing nothing more than returning to his royal headquarters in Hyrcania likely is too dismissive.

127 Grainger (2013), 183-184 assumes the Parthians' invasion of Mesopotamia would not have been possible without the collapse of Bactria under nomadic pressures. Yet Mithridates had already defeated Bactria, severely limiting the threat that the Bactrians posed to Parthia's eastern frontier. In fact, the collapse of Bactria made Parthia's eastern frontier far more vulnerable because of the heighten nomadic threat that came with it.

128 Sachs and Hunger (1996), no. -140C.

129 Sachs and Hunger (1996), no. -140C; Dą̧browa (2014), 63.

130 App. Syr. 8.47; Diod. Sic. 31.27a; Just. Epit. Prol. 34, 36.1.4-5, 41.6.8; Sachs and Hunger (1996), no. -140C, no. -140D, no. -137B, no. -137C, no. -137D. Note Shayegan (2011), 79-80; Dąbrowa (2014), 63.

131 Sachs and Hunger (1996), no. -140A, no. -140C; Just. Epit. 41.6.6-8.

132 Just. Epit. 41.6.8 states that the Parthians conquered Elymais before conquering Babylonia.

133 Dąbrowa (2006); Shayegan (2011), 67. 
bronze coins (S12.26-28) from its mint in 140-138, Shayegan recently has demonstrated that Elymais and Parthia had an ongoing conflict over Mesopotamia and Susiana until the Parthians finally forced Elymais to recognize Parthian suzerainty in 132 and accept Parthian direct rule in $124 .{ }^{134}$

For several years prior to the conflict with Parthia, Elymais had acted independently of the Seleucid Empire. In 147 in reaction to the destructive civil war between Demetrius II and Alexander Balas, the rulers of Elymais had declared themselves kings and began raiding Babylonia for the next fifteen years. ${ }^{135}$ Thus, Elymais was one of many states within the expanding Iranian interstate system taking advantage of the decline of Seleucid hegemony during the power-transition crisis of the 160s-130s, pursuing power-maximizing policies to increase state security and authority. Much like Bactria, Parthia, and Media before them, Elymais and the other middling and minor states in the Hellenistic Middle East, such as Media Atropatene, Persis, Characene, and Armenia, chafed under Seleucid suzerainty in the first half of the second century. These states desired to rule themselves autonomously; however, until the sudden deterioration of Seleucid power, beginning in the late 160 s and continuing into the 130s, they did not have the capabilities to resist Seleucid retaliation. ${ }^{136}$

The temporary independence of these middling and minor states during the crisis and their aggressive efforts to secure their own power and safety further destabilized the international environment. In an unforgiving system of interstate anarchy like the Iranian interstate system in the 160s-130s, where violence and brutality were constant threats, minor states needed to be highly militarized and bellicose to survive. ${ }^{137}$ Thus, it is not surprising that smaller powers, such as the

134 For the prolonged Parthian conflict with Elymais, see Sachs and Hunger (1996), no. -140C, no. -140D, no. -137D; Assar (2006c), 91-93; Shayegan (2011), 96-98. For the expansionistic aggression of Elymais, see Shayegan (2011), 62-65, 67, 77-98. Note Sachs and Hunger (1996), no. -144. For the Kamnaskiri dynasty and their rule over Elymais in this period, see Shayegan (2011), 88-101, 103, 105-110, 183-187, 325; Dąbrowa (2014). Note Strabo 15.3.12, 16.1.18.

135 Le Rider (1965), 340, 351; Dąbrowa (2014), 61-63.

136 Note Le Rider (1965), 347; Harmatta (1981), 189-217; Callieri (1998); (2003); (2007), 115-146; Schuol (2000); Assar (2004-2005), 27-91; (2006c), 89, 142 n.172; Dąbrowa (2005); Wiesehöfer (2007a); (2011); (2012); (2013); Curtis (2010); Olbrycht (2010a), 229-230, 232, 238-240; Shayegan (2011), 62, 65-67, 77-85, 88-104, 107-108, 110-118, 120, 122, 131, 152, 155-187, 204-207, 324-325; Callieri and Chaverdi (2013), 691; Rezakhani (2013), 772-77; Grainger (2013), 130-131, 136-137; (2015), 76; (2016), Chs. 4-6; Plischke (2014), 287-290; Sampson (2015), 44-45.

137 Joseph. AJ 13.223-229, 236, 240-249, 254-258, 267-269; BJ 1.50-54, 61-63; Hieron. Chron. 165.1-2; I Macc. 15.25-16.10; V Macc. 21.1-18; Diod. Sic. 31.27a, 33.18, 34/35.1; Eus. Chron. (Smith ed.): 255; Plut. Mor. 184E-F; Just. Epit. 39.5.5-6, 41.5.9, 6.1-3, 8; Just. Epit. Prol. 34, 39; Strabo 11.9.2, 15.1.3, 2.11; App. Syr. 8.47; Sachs and Hunger (1996), no. -140A, no. -140C, no. -137B. 
Hasmonean Kingdom, Commagene, Cappadocia, Armenia, Elymais, Characene, Persis, Media Atropatene, Bactria, the Indo-Greek Kingdom, various Arab and central Asian tribes, and especially Parthia all emphasized aggressive militarism against neighboring powers in this period of crisis. ${ }^{138}$ The fracturing of Seleucid hegemony in the middle second century meant that the Seleucids and Parthians not only had to reckon with one another, but also had to contend with several highly militarized, expansionistic middling and minor states in this period.

\section{The Results of the Crisis}

It was in this uncertain, fluid, and dangerous international environment that the Seleucids determined to retaliate in the hegemonic struggle against Parthia. Although recent civil wars, rebellions, and territorial losses to the Parthians had severely damaged the authority of the Seleucid kings and the perceived power of the empire, the Seleucid state remained a major military power in the Hellenistic Middle East with massive resources. ${ }^{139}$ Demetrius II and his successor, Antiochus VII, decided to undertake major eastern campaigns to punish the Parthians, to salvage the deteriorating prestige of the Seleucid state, and to restore the empire to its former glory. ${ }^{140}$ The Parthians had annexed Media, Persis, and Babylonia; however, each of these recent successes had been difficult and none of them had come at the expense of the main Seleucid royal army. The Parthians' conquest of Media against limited Seleucid forces had taken years to accomplish, and the recent Elymaean raids into Babylonia illustrated the fragility of the Parthian occupation of this region. The newly acquired power of Parthia in the east remained quite fragile in 140. A determined, well-executed eastern campaign like that of Antiochus III in 210 could have reversed the recent gains of the Parthians swiftly and reestablished Seleucid hegemony over the Iranian interstate system, at least temporarily.

138 This systemic violence is the "perpetual tragedy of relations between and among states" that Realist theoreticians emphasize. See Waltz (1959), 160; (2000), 8; Arendt (1970), 5; Holsti (1972); (1991); Wight (1978), 101-102, 137; (1979), 102; Thompson (1988), xviii; Liska (1990), 482; Little (1993), 150; Spirtas (1996); Glaser (1997), 177; Geller and Singer (1998); Copeland (2000), 12, 17, 145-147, 165-168, Ch. 8.

139 Although exaggerated, Just. Epit. 38.10.1-2 states that Antiochus VII had 80,000 soldiers with 300,000 camp followers. Diod. Sic. 34/35.17 places the entire force at 300,000. For larger military figures, see Oros. 5.10.8; Eus. Chron. (Smith ed.): 255; I Macc. 15.13. Assar (2011), 118 conservatively surmises that Antiochus' army in the east was closer to 30,000 soldiers. Even this figure is an impressive military force.

140 Josep. AJ 13.184-5; Just. Epit. 38.10.6; Diod. Sic. 34/35.15; I Macc. 15.3, V Macc. 21.19. 
In 138 and 130 Demetrius II and then Antiochus VII had the opportunity, resources, and motivation to conduct major eastern expeditions against the Parthians. Yet both campaigns proved disastrous as they and their armies became isolated and fell victim to the Parthians' mobile and deceptive mode of warfare. ${ }^{141}$ With these decisive victories, the Parthians established themselves firmly as the hegemonic rivals and geopolitical equals of the Seleucids within the Hellenistic Middle East. Antiochus VII's eastern campaign was the last great gasp of the Seleucid Empire, and the Parthians' victory provided them with an opening to push their advantage into the lands of the Near East for the first time.

Ultimately, Parthia under the leadership of Mithridates I emerged from the crisis as the most successful of numerous competing polities for three main reasons. First, the Parthians' relatively moderate and inclusive style of governing aided them in their efforts to absorb huge swaths of territory throughout the Iranian plateau and Mesopotamia. ${ }^{142}$ The Parthians embraced regional aristocracies and incorporate them into a more flexible structure of empire. ${ }^{143}$ The Parthian state from its conception built upon the social flexibility of a multi-cultural union of regional leaders under the ultimate authority of the Arsacids. ${ }^{144}$ This made the high command of the Parthian state versatile and eclectic, allowing the Arsacids to develop a more inclusive system of administration that emphasized, utilized, and internalized the capabilities and strengths of local leaders. ${ }^{145}$ Although the Achaemenids utilized administrative inclusiveness and cultural flexibility to gain and maintain support within their massive empire, the Seleucids failed to persuade sufficiently "indigenous elites to identify imperial interest with their own." 146 The more dismissive and exploitative occupation of the multi-cultural eastern territories by the Seleucids, which in the examples of Seleucus II, Antiochus III, Antiochus IV, and Antiochus VII resulted in disaster, created local re-

141 Note Just. Epit. 36.1.4-5, 38.9.2, 10.9-10, 39.1.1-2; Epit. Prol. 35-6; App. Syr. 11.67; Joseph AJ 13.186, 218-9; I Macc. 14.2-3; Diod. Sic. 33.28.1, 34/35.17.2. For the Parthians' mode of warfare, see Overtoom (2017b).

142 Diod. Sic. 33.18 emphasizes the inclusiveness of Parthian society, which internalized the "best

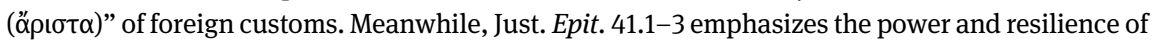
the Parthians.

143 Dąbrowa (2011); Wiesehöfer (2016), 227; Gregoratti (2016b), 86-89; (2017a).

144 Arsaces I helped establish this precedent when he quickly convinced the Parthian aristocracy in northeastern Iran to support him and his dynasty against the interests of the Seleucid state and its officials. Frye (1984), 208; Shahbazi (1986); Olbrycht (2003), 73-75; Overtoom (2016a).

145 Keall (1994), 271-272; Dąbrowa (2013); Wiesehöfer (2016), 217-218; Gregoratti (2017a); Olbrycht (2017).

146 Kosmin (2013), 686; Chrubasik (2016), Ch. 1. For the Achaemenids, note Wiesehöfer (1996), 66-101; Briant (2002), 873-876; Lerner (2015a), 304-305. 
sentment on a scale that the Parthians rarely encountered. ${ }^{147}$ Thus, compared to the Seleucid occupation of the Middle East, indigenous aristocrats had heightened regional autonomy and power under the Parthians with greater access to authority and participation within the Parthian imperial system. ${ }^{148}$

Second, the composition of the Parthian military, its use in the field, and its ability to maintain a major imperial state allowed the Parthians to dominate the Hellenistic Middle East. The Parthians utilized a mixture of swift, light-armed horse archers and perhaps the most devastating and versatile heavy cavalry in the world in this period to outmaneuver and overwhelm their competitors. ${ }^{149}$ Since the Parthians' professional standing army was relatively small, they utilized their network of vassal kingdoms to raise necessary levies and share the military burden of controlling such a large imperial territory. ${ }^{150}$ The Parthians' developed a highly effective approach to warfare that allowed smaller, more logistically limited, and lighter-armed Parthian armies to resist and annihilate the more professionalized and heavier-armed armies of the Seleucids and Romans through speed, maneuverability, flexibility, and deception. ${ }^{151}$

Finally, the generally good leadership and relative stability of the Arsacids went hand-in-hand with the success of the Parthian state in this period. Unlike the Seleucids and Bactrians, who became crippled by dynastic strife during the crisis, the Arsacids did not experience a civil war until the late 90s BCE. ${ }^{152}$ The stability of the monarchy during their early history gave the Parthians another important advantage in their struggle to dominate the Hellenistic Middle East. When the Parthian king was a capable and commanding figure, like Mithridates I, the state prospered; however, when the king was weak, or the throne was contested, something that occurred far too frequently after the late 90s, the power of the state dwindled. The expanding power of the Parthian aristocracy played an

147 Overtoom (2016c), Chs. 1-3.

148 Wolski (1989); Olbrycht (2010b), 147; (2017); Grajetzki (2011), 11, 15; Wiesehöfer (2016), 217218, 227; Gregoratti (2016a), 5.

149 Wilcox (1986); Shahbazi (1987); Nikonorov (1995); Warry (1995), 154-156; Mielczarek (1998); Olbrycht (1998b); (2001); (2003), 94-95; (2015a); Nikonorov (2005); (2010); Lerouge-Cohen (2007), 285-313; Sheldon (2010); Traina (2010); Sampson (2015); Anderson (2016); Overtoom (2017b); (2018).

150 Note Wilcox (1986), 6; Hauser (2006); (2013); Olbrycht (2016a); Overtoom (2017b). Some scholars suggest the Arsacids only maintained weak control over the army or that the Parthian military was an inexperienced militia: Colledge (1967), 66, 75; Sheldon (2010), 175. Such notions have been dismissed in recent years. See Hauser (2006); Hauser (2013), 734-739; Olbrycht (2016a); Overtoom (2017b).

151 Overtoom (2017a); (2017b).

152 Assar (2005a), 53; (2005b); (2006b), 56-62; (2011), 121-122. 
important role in the long cycle of civil wars that sapped the strength of the Arsacids from the first century onward. ${ }^{153}$ Yet the capable and ambitious early Arsacids were indispensable to the formation and expansion of the Parthian state from a minor kingdom to a major empire.

Thus, Mithridates I's leadership indeed was crucial to the success of the Parthian state in the 160s-130s, and his many conquests established him as one of the greatest kings of Parthia. ${ }^{154}$ Yet the environment in which he operated also is an important factor to consider. Without the power-transition crisis of the 160s130s caused by the rapid collapse of Bactria and the death of Antiochus IV, the success Mithridates achieved would have been far more difficult and perhaps impossible. The death of Antiochus saved Parthia from a major invasion; the numerous distractions hamstringing Eucratides I's regime in Bactria made easy eastern expansion possible; and the debilitating civil wars in Syria exposed Media and Mesopotamia to conquest. Understanding the circumstances of Mithridates' reign is critical to appreciating his true accomplishments. He was not a unique leader in his desires to consolidate and expand his power; however, his capabilities were significant, and his opportunities were immense.

In the 160s-130s, Mithridates I was well-placed at the head of an ascending power during a period of widespread crisis to capitalize on the greatest opportunity the Parthians had had to greatly expand their power and influence since the 240s-230s. The crisis drastically changed the makeup of the international environment and created a power vacuum throughout much of the Hellenistic Middle East that the Parthians eagerly and expertly filled. Justin (Epit. 41.1.6-9) in the introduction of his Parthian history states,

It must seem wonderful to everyone, that they [the Parthians] should have reached such a height of good fortune as to rule over those nations under whose sway they had been merely slaves. Being assailed by the Romans, also, in three wars, under the conduct of the greatest generals, and at the most flourishing period of the republic, they alone, of all nations, were not only a match for them, but came off victorious; though it may have been a greater glory to them, indeed, to have been able to rise amidst the Assyrian, Median, and Persian empires, so celebrated of old, and the most powerful dominion of Bactria, peopled with a thousand cities, than to have been victorious in war against a people [the Romans] that came from a distance; especially when they were continually harassed by severe wars with the Scythians and other neighboring nations, and pressed with various other formidable contests.

153 Wolski (1967); (1989); Dąbrowa (2013); Gregoratti (2013).

154 It appears Mithridates quickly was deified because his son Phraates II minted coinage inscribed with "Son of a Divine Father” (S16). Assar (2011), 118. 
Justin here labels the Parthians as the successors and equals of the greatest eastern empires, and he champions the significance of the Parthians' rise to power, stressing the continued success of the Parthians in their numerous military confrontations. Although the rivalry with the Seleucids continued for another half century and soon after the rivalry with the Romans lasted another three centuries, the Parthians meteoric rise in the second century earned them a place in history as one of the world's greatest powers. ${ }^{155}$

\section{Bibliography}

Anderson, E. Cataphracts: knights of the ancient eastern empires. Barnsley: Pen and Sword, 2016.

Arendt, H. On Violence. New York: Harcourt, Brace and World, 1970.

Aron, R. Peace and War: a theory of international relations. Garden City: Doubleday, 1973.

Assar, G. "Genealogy and coinage of the early Parthian rulers I." Parthica 6 (2004): 69-93.

Assar, G. "History and coinage of Elymais during 150/149-122/121 BC." International Journal of Ancient Iranian Studies 8 (2004-2005): 27-91.

Assar, G. "Genealogy and coinage of the early Parthian rulers II: a revised stemma." Parthica 7 (2005a): 29-63.

Assar, G. "The genealogy of the Parthian king Sinatruces." Journal of the Classical and Medieval Numismatic Society 6.2 (2005b): 16-33.

Assar, G. "The terminal date of the reign of Mithridates I of Parthia." Bulletin of Ancient Iranian History 2 (2006a): 1-16.

Assar, G. "A revised Parthian chronology of the period 91-55 BC." Parthica 8 (2006b): 55-104.

Assar, G. "A revised Parthian chronology of the period 165-91 BC." Electrum 11 (2006c): 87-158.

Assar, G. "Arsaces IV (c. 170-168 BC) the 1st 'missing' Parthian king." International Journal of Ancient Iranian Studies 6.1-2 (2006-2007): 3-14.

Assar, G. "Iran under the Arsacids, 247 BC - AD 224/227." In Numismatic Art of Persia, edited by B. Nelson, 113-171. Lancaster: Lancaster Numismatic Group, 2011.

Balakhvantsev, A. Political History of Early Parthia. Moscow: Institute of Oriental Studies of the Russian Academy of Sciences, 2017.

Bederman, E. International Law in Antiquity. Cambridge: Cambridge U. P., 2001.

Benjamin, C. The Yuezhi: origin, migration, and the conquest of northern Baktria. Turnhout: Isd., 2007.

Bivar, A. "The political history of Iran under the Arsacids." In Cambridge History of Iran. Volume 3.1, edited by E. Yarshater, 21-99. Cambridge: Cambridge U. P., 1983.

Boillet, P. "Quantifying monetary production: Ecbatana and Media in Parthian times." In The Parthian and Early Sasanian Empires, edited by V. Curtis, et al., 109-122. Oxford: Oxbow, 2016.

Boiy, T. Late Achaemenid and Hellenistic Babylon. Leuven: Peeters, 2004.

155 Overtoom (2016b); (2016c); (2017a); (2017b). 
Bopearachchi, O. Monnaies gréco-bactriennes et indo-grecques, Catalogue raisonné. Paris: Bibliothèque nationale, 1991.

Brecher, M. and J. Wilkenfeld. “Crises in world politics.” World Politics 34 (1982): 380-417.

Briant, P. From Cyrus to Alexander: a history of the Persian Empire. University Park: Eisenbrauns, 2002.

Buzan, B., C. Jones and R. Little, editors. The Logic of Anarchy. New York: Columbia U. P., 1993.

Callieri, P. “A proposito di un'iconografia monetale dei dinasti del Fars post-achemenide." Ocnus 6 (1998): 25-38.

Callieri, P. "Some notes on the so-called Temple of the Fratarakas at Persepolis." In Studi in onore di Umberto Scerrato: per il suo settantacinquesimo compleanno, Volume One, edited by M. Fontana and B. Genito, 153-165. Naples: Università degli studi di Napoli L'Orientale, 2003.

Callieri, P. L'archéologie du Fars à l'époque hellénistique. Paris: De Boccard, 2007.

Callieri, P. “Sakas: in Afghanistan.” Encyclopaedia Iranica (2016). 5 2018. <http://www.iranicaonline.org/articles/sakas-in-afghanistan>.

Callieri, P. and A. Chaverdi. "Media, Khuzestan, and Fars between the end of the Achaemenids and the rise of the Sasanians." In Potts 2013, 690-717.

Campbell, B. "War and diplomacy: Rome and Parthia, 31 BC - AD 235." In War and Society in the Roman World, edited by J. Rich and G. Shipley, 213-240. London: Psychology, 1993.

Canepa, M. "Topographies of Power: Theorizing the Visual, Spatial and Ritual Contexts of Rock Reliefs in Ancient Iran.” In Of Rocks and Water, edited by Ö. Harmansah, 53-92. Oxford: Oxbow, 2014.

Canepa, M. "Dynastic sanctuaries and the transformation of Iranian kingship between Alexander and Islam." Persian Kingship and Architecture, edited by S. Babaie and T. Grigor, 67-77. London: I. B. Tauris, 2015.

Chilver, G. and G. Townend. A Historical Commentary on Tacitus' Histories IV and V. Oxford: Clarendon, 1985.

Chrubasik, B. Kings and Usurpers in the Seleukid Empire: the men who would be king. Oxford: Oxford U. P., 2016.

Colledge, M. The Parthians. New York: Praeger, 1967.

Coloru, 0. "Antiochos IV et le royaume de Médie Atropatène: nouvelles considérations sur un mariage dynastique entre Séleucides et la maison d'Atropatès." In Le projet politique d'Antiochos IV, edited by C. Feyel and L. Graslin-Thomé, 395-414. Nancy: A. D. R. A., 2014.

Copeland, D. “Neorealism and the myth of bipolar stability." Security Studies 5.3 (1996): 29-89.

Copeland, D. The Origins of Major War. Ithaca: Cornell U. P., 2000.

Curtis, V. "The Frataraka coins of Persis: bridging the gap between Achaemenid and Sasanian Persia." The World of Achaemenid Persia, edited by J. Curtis and S. Simpson, 379-396. London: I. B. Tauris, 2010.

Dąbrowa, E. “L’Expédition de Démétrios II Nicator contre les Parthes (139-138 avant J.-C.).” Parthica 1 (1999 [2000]): 9-17.

Dąbrowa, E. “Les Aspects politiques et militaires de l'invasion de la Mésopotamie par les Parthes." Electrum 10 (2005): 73-88.

Dąbrowa, E. "The conquests of Mithridates I and the numismatic evidence." Parthica 8 (2006): 37-40.

Dąbrowa, E. “The Parthian kingship."In Concepts of Kingship in Antiquity, edited by G. Lanfranchi and R. Rollinger, 123-134. Padova: S. A. R. G. O. N., 2010. 
Dąbrowa, E. Studia Graeco-Parthica: political and cultural relations between Greeks and Parthians. Wiesbaden: Harrassowitz, 2011.

Dąbrowa, E. “The Parthian aristocracy: its social position and social activity." Parthica 15 (2013): 53-62.

Dąbrowa, E. “A troublesome vassal? Elymais and Parthia (141 BC-AD 228).” Parthica 16 (2014): 61-68.

Dąbrowa, E. "Roman authors on the honours of Arsaces I: observations on the transmission of a historical tradition." Latomus 75.3 (2016): 573-584.

Daffinà, P. L'immigrazione dei Saka nella Drangiana. Rome: Istituto italiano per il Medio ed Estremo Oriente, 1967.

Daryaee, T. "Western and central Eurasia." In Cambridge World History. Volume 4, edited by C. Benjamin, 271-299. Cambridge: Camridge U. P., 2015.

Debevoise, N. A Political History of Parthia. Chicago: University of Chicago, 1938.

Eckstein, A. Moral Vision in the Histories of Polybius. Berkeley: University of California, 1995.

Eckstein, A. "Thucydides, the outbreak of the Peloponnesian War, and the foundation of international systems theory." International History Review 23 (2003): 757-774.

Eckstein, A. "Bellicosity and anarchy: soldiers, warriors, and combat in antiquity." International History Review 27.3 (2005): 481-497.

Eckstein, A. Mediterranean Anarchy, Interstate War, and the Rise of Rome. Berkeley: University of California, 2006.

Eckstein, A. Rome Enters the East: from anarchy to hierarchy in the Hellenistic Mediterranean, 230-170 BC. Chichester: Wiley-Blackwell, 2012.

Eckstein, A. "What is an empire and how do you know when you have one? Rome and the Greek states after 188 BC." Culture, Identity and Politics in the Ancient Mediterranean World, edited by P. Burton and E. Gruen, 173-190. Canberra: Australasian Society for Classical Studies, 2013.

Eilers, C., editor. Diplomats and Diplomacy in the Roman World. Leiden: Brill, 2009.

Engels, D. Benefactors, Kings, Rulers: studies on the Seleukid Empire between East and West. Leuven: Peeters, 2017.

Ferguson, R. "Rome and Parthia: power politics and diplomacy across cultural frontiers." CEWCES Research Papers 10 (2005): 1-38.

Frye, R. The History of Ancient Iran. Munich: C. H. Beck, 1984.

Gabelko, O. "The dynastic history of the Hellenistic monarchies of Asia Minor." Mithridates VI and the Pontic Kingdom, edited by J. Højte, 47-62. Aarhus: Aarhus U. P., 2009.

Geller, D. and J. Singer. Nations at War: a scientific study of international conflict. Cambridge: Camridge U. P., 1998.

Gilpin, R. War and Change in World Politics. Cambridge: Cambridge U. P., 1981.

Gilpin, R. "Theory of hegemonic war." Journal of Interdisciplinary History 18 (1988): 591-613.

Glaser, C. "The security dilemma revisited." World Politics 50 (1997): 171-201.

Gochman, C. and Z. Maoz. "Militarized interstate disputes, 1816-1976: procedures, patterns and insights." Journal of Conflict Resolution 28 (1983): 585-616.

Grainger, J. A Seleukid Prosopography and Gazetter. Leiden: Brill, 1997.

Grainger, J. The Roman War of Antiochos the Great. Leiden: Brill, 2002.

Grainger, J. The Wars of the Maccabees. Barnsley: Pen and Sword, 2012.

Grainger, J. Rome, Parthia, India: the violent emergence of a new world order 150-140 BC.

Barnsley: Pen and Sword, 2013. 
Grainger, J. The Rise of the Seleukid Empire (323-223 BC): Seleukos I to Seleukos III. Barnsley: Pen and Sword, 2014.

Grainger, J. The Seleukid Empire of Antiochus III (223-187 BC). Barnsley: Pen and Sword, 2015. Grainger, J. The Fall of the Seleukid Empire 187-75 BC. Barnsley: Pen and Sword, 2016.

Grainger, J. Kings and Kingship in the Hellenistic World 350-30 BC. Barnsley: Pen and Sword, 2017 a.

Grainger, J. Great Power Diplomacy in the Hellenistic World. London: Routledge, 2017b.

Grajetzki, W. Greeks and Parthians in Mesopotamia and Beyond 331 BC - 224 AD. London: Bloomsbury Academic, 2011.

Grant, J. "A note on the tone of Greek diplomacy." CQ 12 (1962): 261-6.

Gregoratti, L. "A Parthian port on the Gulf Coast: Characene and its trade." Anabasis 2 (2011): 209-225.

Gregoratti, L. "The journey east of the Great King: east and west in the Parthian Kingdom.” Parthica 15 (2013): 43-63.

Gregoratti, L. "Parthian Empire.” In The Encyclopedia of Empires, edited by J. Mackenzie, 1-6. Hoboken: Wiley-Blackwell, 2016 a.

Gregoratti, L. "Legendary and real wealth in the Arsacid kingdom." In Studies on Wealth in the Ancient World, edited by E. Bissa and F. Santangelo, 83-92. London: Institute for Classical Studies, 2016b.

Gregoratti, L. "Sinews of the other empire: the Parthian Great King's rule over vassal kingdoms." In Sinews of Empire, edited by E. Seland, 95-104. Havertown: Casemate, 2017 a.

Gregoratti, L. “The Arsacid Empire.” In King of the Seven Climes, edited by T. Daryaee, et al., 125-153. Irvine: UCI Jordan Center for Persian Studies, 2017b.

Gruen, E. The Hellenistic World and the Coming of Rome. Berkeley: University of California, 1984. Habicht, C. "The Seleucids and their rivals." Cambridge Ancient History. Volume 8.2, edited by I. Edwards, et al., 324-387. Cambridge: Cambridge U. P., 1989.

Hansman, J. "Characene and Charax." Encyclopaedia Iranica (2011) 5 2018. <http://www.iranicaonline.org/articles/characene-and-charax-spasinou-in-pre-islamic-times $>$

Harmatta, J. "Parthia and Elymais in the second century BC." Acta Antiqua Academiae Scientiarum Hungaricae 29 (1981): 189-217.

Hauser, S. "Was there no paid standing army? A fresh look on military and political institutions in the Arsacid Empire." In Arms and Armour as Indicators of Cultural Transfer, edtied by M. Mode and J. Tubach, 295-319. Wiesbaden: Reichert, 2006.

Hauser, S. “The Arsacids (Parthians).” In Potts 2013 728-750.

Hill, S. Defining the alter orbis: The Roman View of Parthia in the Early Principate. (Diss.) University of Wales, 2013.

Holsti, K. Peace and War: armed conflicts and international order, 1648-1989. Cambridge: Cambridge U. P., 1991.

Holt, F. Alexander the Great and Bactria: the formation of a Greek frontier in central Asia. Leiden: Brill, 1988.

Holt, F. Thundering Zeus: the making of Hellenistic Bactria. Berkeley: University of California, 1999.

Holt, F. Lost World of the Golden King: In search of ancient Afghanistan. Berkeley: University of California, 2012a.

Holt, F. "When did the Greeks abandon Aï Khanoum?" Anabasis 3 (2012b): 161-172.

Howarth, R. "War and warfare in ancient Rome." In Oxford Handbook of Warfare in the Classical World, edited by J. Campbell and L. Tritle, 29-45. Oxford: Oxford U. P., 2013. 
Hoyos, D. Hannibal's Dynasty: power and politics in the western Mediterranean, 247-183 BC. London: Routledge, 2003.

Huntington, S. "Why international primacy matters." International Security 17 (1993): 68-83. Jakobsson, J. “Indo-Greek chronology c. 200-145." Journal of the Oriental Numismatic Society 198 (2009): 8-12.

Jenkins, G. “Notes on Seleucid coins.” Numismatic Chronicle 6.11 (1951): 1-21.

Jervis, R. Perception and Misperception in International Politics. Princeton: Princeton U. P., 1976.

Jervis, R. “Cooperation under the security dilemma." World Politics 30 (1978): 167-214.

Jervis, R. "Variation, change, and transitions in international politics." Review of International Studies 27 (2001): 281-295.

Karras-Klapproth, M. Prosopographische Studien zur Geschichte des Partherreiches auf der Grundlage antiker literarischer Überlieferung. Bonn: R. Habelt, 1988.

Keall, E. “How many kings did the Parthian King of Kings rule?” Iranica Antiqua 29 (1994): 254-272.

Keeley, L. War Before Civilization: the myth of the peaceful savage. Oxford: Oxford U. P., 1999.

Kissinger, H. A World Restored: Castlereagh, Metternich, and the problem of Peace, 1812-1822. Boston: Houghton Mifflin, 1957.

Kosmin, P. "Alexander the Great and the Seleucids in Iran." In Potts 2013a, 671-689.

Kosmin, P. "Rethinking the Hellenistic gulf: the new Greek inscription from Bahrain.” JHS 133 (2013b): 61-79.

Kosmin, P. The Land of the Elephant Kings: space, territory, and ideology in the Seleucid Empire. Cambridge: Harvard U. P., 2014.

Le Rider, G. Suse sous les Séleukides et les Parthes. Paris: P. Geuthner Limoges, 1965.

Lemke, D., and J. Kugler. "The evolution of the power transition perspective." In Parity and War, edited by J. Kugler and D. Lemke, 3-33. Ann Arbor: University of Michigan, 1996.

Lerner, J. The Impact of Seleucid Decline on the Eastern Iranian Plateau: the foundations of Arsacid Parthia and Graeco-Bactria. Stuttgart: Franz Steiner, 1999.

Lerner, J. "Revising the chronologies of the Hellenistic colonies of Samrakand-Marakanda (Afrasiab II-III) and Ai Khanoum (northeastern Afghanistan)." Anabasis 1 (2010): 58-79.

Lerner, J. "Reappraisal of the economic inscriptions and coin finds from Aï Khanoum." Anabasis 2 (2011): 103-147.

Lerner, J. "Regional study: Baktria - the crossroads of ancient Eurasia." In Cambridge World History. Volume 4, edited by C. Benjamin, 300-324. Cambridge: Camridge U. P., 2015a.

Lerner, J. “Mithridates I's conquest of western Greek-Baktria." Journal of History, Philology and Cultural Studies 47.1 (2015b): 45-55.

Lerner, J. "The emergence of Wakhan fortresses in the Hellenistic period." Anabasis 7 (2016): 107-130.

Lerner, J. "Mithridates I and the Parthian archer." In Arsacids, Romans and Local Elites, edited by J. Schlude and B. Rubin, 1-24. Oxford: Oxbow, 2017.

Lerouge-Cohen, C. L'image des Parthes dans le monde gréco-romain: du début du ler siècle av. J.-C. jusqu'à la fin du Haut-Empire romain. Stuttgart: Franz Steiner, 2007.

Levy, J. “Theories of general war." World Politics 37.3 (1985): 344-374.

Liska, G. Career of Empire: America and imperial expansion over land and sea. Baltimore: Johns Hopkins U. P., 1978.

Liska, G. The Ways of Power: pattern and meaning in world politics. Oxford: Basil Blackwell, 1990.

Little, R. “Structure and logic of anarchy.” In Buzan, Jones and Little 1993, 132-154. 
Mair, V., et al., editor. A Concise Commentary on Memoirs on the Western Regions in the Official Histories of the Western and Eastern Han, Wei, Jin, and Southern and Northern Dynasties. Trans. Y. Taishan. Beijing: Commercial, 2014.

Marcus, R., editor. Josephus' Jewish Antiquities. Volume 7. Loeb Classical Library. Cambridge: Harvard U. P., 1943.

Martinez-Sève, L. “Antiochos IV en Susiane, dans le Golfe Persique et en Élymaïde.” In Le projet politique d'Antiochos IV, edited by C. Feyel and L. Graslin-Thomé, 363-393. Nancy:

A. D. R. A., 2014.

Masson, V. "O severo-vostochnykh predelach parfyanskogo gosudarstva." Krakie soobshcheniya instituta materyal'noy kul'tury 38 (1951): 145-151.

Matyszak, P. Mithridates the Great: Rome's indomitable enemy. Barnsley: Pen and Sword, 2008. Mearsheimer, J. "The false promise of international relations." International Security 19.3 (1994-1995): 5-49.

Mearsheimer, J. The Tragedy of Great Power Politics. New York: Norton, 2001.

Midlarsky, M. The Onset of World War. Boston: Routledge, 1988.

Mielczarek, M. "Cataphracts - a Parthian element in the Seleucid art of war." Electrum 2 (1998): 101-106.

Mittag, P. Antiochus IV Epiphanes: Eine politische Biographie. Berlin: Akademie, 2006.

Moore, C., editor. Tacitus: The Histories Books IV-V. Loeb Classical Library. Cambridge: Harvard U. P., 1931/2005.

Mukherjee, B. "An examination of the theory of the occupation of the Greek Bactria by Mithridates I." Journal of Asiatic Society 11 (1969): 1-5.

Müller, S. “Das Bild der Parther bei Trogus-Justin.” In Wiesehöfer and Müller 2017b, 241-258.

Narain, A. The Indo-Greeks. Oxford: Oxford U. P., 1957.

Nikonorov, V. “K voprosu o parfianskoi taktike (na primere bitvy pri Karrakh).” In Voennoe delo i srednevekovaia arkheologiia Tsentral'noi Azii, 53-61. Kemerovo: Kemerovo State University, 1995.

Nikonorov, V. "On the Parthian legacy in Sasanian Iran: the case of warfare." In Central Asia from the Achaemenids to the Timurids, edited by V. Nikonorov, 141-179. St. Petersburg: Institute of the History of Material Culture of the Russian Academy of Sciences, 2005.

Nikonorov, V. "On the contribution of the central Asian nomads to the warfare of the antique civilization (by the Example of Iran)." In The Role of Nomads of the Eurasian Steppes in the Development of World Military Art, edited by I. Yerofeyeva, B Zhanayev, and L. Masanova, 43-65. Almaty: 〈<LEM〉>, 2010.

Olbrycht, M. Parthia et ulteriores gentes. Die politischen Beziehungen zwischen demarsakidischen Iran und den Nomaden der eurasischen Steppen. Munich: Tuduv, 1998a.

Olbrycht, M. "Parthian military strategy at wars against Rome." In Military Archaeology, edited by G. Vilnibahov, 138-141. St. Petersburg: Institute of the History of Material Culture of the Russian Academy of Sciences, 1998b.

Olbrycht, M. "The origins of the Arsacid Parthian cavalry: some remarks." In The Role of Ahalteke Horses in the Formation of World Horse-Breeding, edited by V. Masson, 108-111. Ashgabat: The Rukhname Presidential Programme, 2001.

Olbrycht, M. "Parthia and nomads of central Asia. Elements of steppe origin in the social and military development of Arsacid Iran." Militär und Staatlichkeit, Orientwissenschaftliche Hefte 12.2003, edited by I. Schneider, 69-110. Halle: Orientwissenschaftliches Zentrum der Martin-Luther-Universität Halle-Wittenberg, 2003. 
Olbrycht, M. "Mithradates I of Parthia and his conquests up to 141 BC." In Hortus Historiae, edited by E. Dabrowa, 229-245. Krakow: Historia lagellonica, 2010 a.

Olbrycht, M. "The early reign of Mithradates II the Great in Parthia." Anabasis 1 (2010b): 144-158.

Olbrycht, M. "Eastern Baktria under Da Yuezhi hegemony." In Glory of the Kushans, edited by V. Jayaswal, 79-86. New Delhi: Aryan Books, 2012.

Olbrycht, M. "Arsacid Iran and the momads of central Asia - ways of cultural transfer." In Complexity of Interaction Along the Eurasian Steppe Zone in the First Millennium CE, edited by J. Bemmann, 333-390. Bonn: Vor- und Frühgeschechtliche Archäologie, 2015 a.

Olbrycht, M. "Persia beyond the imperial frontiers: the nomads of the south Ural region versus the Near East." Anabasis 6 (2015b): 257-275.

Olbrycht, M. "Manpower resources and army organisation in the Arsakid Empire." Ancient Society 46 (2016a): 291-338.

Olbrycht, M. "Ruler cult in the Parthian Empire." In Боги среди людей (Gods among People), edited by K. Atkinson, 451-475. Moscow: Azbuka, 2016b.

Olbrycht, M. “Greeks in the Arsacid Empire.” In Wiesehöfer and Müller 2017, 3-28.

Organski, A. and J. Kugler. The War Ledger. Chicago: University of Chicago, 1980.

Overtoom, N. L. "The power-transition crisis of the 240 s and the creation of the Parthian state." International History Review 38.5 (2016a): 984-1013.

Overtoom, N. L. "The rivalry of Rome and Parthia in the sources from the Augustan age to Late Antiquity.” Anabasis 7 (2016b): 137-174.

Overtoom, N. L. Challenging Roman Domination: the end of Hellenistic rule and the rise of the Parthian state from the third to the first centuries. (Diss.) Louisiana State University, 2016 c.

Overtoom, N. L. "The Parthian rival and Rome's failure in the east: Roman propaganda and the stain of Crassus." Acta Antiqua Academiae Scientiarum Hungaricae 57.4 (2017a): 415-435.

Overtoom, N. L. “The Parthians' unique mode of warfare: a tradition of Parthian militarism and the Battle of Carrhae." Anabasis 8 (2017b): 99-122.

Overtoom, N. L. "Considering the failures of the Parthians against the invasions of the central Asian tribal confederations in the 120s BCE." Studia Iranica 47.2 (2018).

Plischke, S. Die Seleukiden und Iran: Die seleukidische Herrschaftspolitik in den östlichen Satrapien. Wiesbaden: Harrassowitz, 2014.

Potts, D., editor. Oxford Handbook of Ancient Iran. Oxford: Oxford U. P., 2013.

Plischke, S. "Persianism under the early Seleukid kings? The royal title 'Great King'." In Persianism in Antiquity, edited by R. Strootman and M. Versluys, 163-176. Stuttgart: Franz Steiner, 2017.

Rezakhani, K. “Arsacid, Elymaean, and Persid coinage.” In Potts 2013, 766-778.

Rezakhani, K. "From Aramaic to Pahlavi: epigraphic observations based on the Persis coin series." In The Parthian and Early Sasanian Empires, edited by V. Curtis, et al., 69-75. Oxford: Oxbow, 2016.

Robert, L. "Samothrace: excavations conducted by the Institute of Fine Arts, New York." Gnomon 35 (1963): 50-79.

Robert, L. "Encore une inscription Grecque de l'Iran." Comptes rendus des séances de l'Académie des Inscriptions et Belles-Lettres 111.2 (1967): 281-297.

Rtveladze, E. "Parthians in the Oxus Valley: struggle for the Great Indian Road." Anabasis 2 (2011): 149-178. 
Sachs, A. and H. Hunger. Astronomical Diaries and Related Texts from Babylon: diaries from 164 $B C$ to 61 BC. Vienna: Abraham Sachs, 1996.

Sachs, A. and D. Wiseman. "A Babylonian king list of the Hellenistic period.” Iraq 15 (1954): 202-211.

Sampson, G. The Defeat of Rome: Crassus, Carrhae and the invasion of the east. Barnsley: Pen and Sword, 2015.

Sartre, M. The Middle East Under Rome. Trans. C. Porter and E. Rawlings. Cambridge: Belknap, 2005.

Sartre, M. "Review of Eckstein, Mediterranean Anarchy." Topoi 15 (2007): 619-625.

Schelling, T. "The diplomacy of violence." In International Politics, edited by R. Art and R. Jervis, 169-183. New York: Longman, 2000.

Schippmann, K. Grundzüge der parthischen Geschichte. Darmstadt: Wissenschaftliche Buchgesellschaft, 1980.

Schuman, F. International Politics. New York: McGraw-Hill, 1969.

Schuol, M. Die Charakene: Ein mesopotamisches Königreich in hellenistisch-parthischer Zeit. Stuttgart: Franz Steiner, 2000.

Shahbazi, A. “Arsacids - Origins." Encyclopaedia Iranica (1986). 3 2016. <http://www.iranicaon line.org/articles/arsacids-index>.

Shahbazi, A. “ASB i. In Pre-Islamic Iran.” Encyclopaedia Iranica (1987). 9 2018. <http://www. iranicaonline.org/articles/asb-pre-islamic-iran>.

Shayegan, M. R. “On Demetrius II Nicator's Arsacid captivity and second rule." Bulletin of the Asia Institute 17 (2003 [2007]): 83-103.

Shayegan, M. R. Arsacids and Sasanians: political ideology in post-Hellenistic and Late Antique Persia. Cambridge: Cambridge U. P., 2011.

Sheehan, M. The Balance of Power: history and theory. London: Routledge, 1996.

Sheldon, R. Rome's Wars in Parthia: blood in the sand. London: Valentine Mitchell, 2010.

Sherwin-White, S. and A. Kuhrt. From Samarkhand to Sardis: a new approach to the Seleucid Empire. Berkeley: University of California, 1993.

Spirtas, M. "A house divided: tragedy and evil in realist theory." In Realism: restatements and renewal, edited by B. Frankel, 385-423. London: Frank Cass \& Co., 1996.

Strootman, R. "Review of Grainger, The Roman War of Antiochos the Great." Bryn Mawr Classical Review 03.52 (2004).

Strootman, R. "Hellenistic court society: the Seleucid imperial court under Antiochus the Great, 223-187 BCE." In Royal Courts in Dynastic States and Empires, edited by J. Duindam,

M. Kunt and A. Tülay, 63-89. Leiden: Brill, 2011.

Strootman, R. "Hellenistic imperialism and the idea of world unity." In The City in the Classical and Post-Classical World, edited by C. Rapp and H. Drake, 38-61. Cambridge: Cambridge U. P., 2014.

Strootman, R. “Seleucus.” Encyclopaedia Iranica (2015). 4 2018. <http://www.iranicaonline.org/ articles/seleucus-kings>.

Strootman, R. "The coming of the Parthians: crisis and resilience in Seleukid Iran in the reign of Seleukos II."In War Within the Family, edited by K. Erickson, 129-150. Swansea: Classical Press of Wales, 2016.

Strootman, R. “Imperial Persianism: Seleukids, Arsakids and Fratarakā.” In Persianism in Antiquity, edited by R. Strootman and M. Versluys, 177-200. Stuttgart: Franz Steiner, 2017.

Strootman, R. "The Great Kings of Asia: universalistic titulature in the Seleukid and post-Seleukid east.” In Seleukeia, edited by R. Oetjen and F. Ryan, 1-29. Berlin: De Gruyter, 2019. 
Taliaferro, J. "Security seeking under anarchy: defensive realism revisited." International Security 25 (2000-2001): 128-161.

Tarn, W. "Parthia in the time of the Roman Republic 133-44 BC." In Cambridge Ancient History. First Edition, Volume 9.1, edited by S. Cook, et al., 574-614. Cambridge: Cambridge U. P., 1932.

Taylor, M. Antiochus the Great. Barnsley: Pen and Sword, 2013.

Taylor, M. "Sacred plunder and the Seleucid Near East." Greece \& Rome 61.2 (2014): 222-241.

Thompson, W. On Global War: Historical-Structural Approaches to World Politics. Columbia: University of South Carolina, 1988.

Torday, L. Mounted Archers - the Beginnings of Central Asian History. Durham: Durham Academic, 1997.

van Evera, S. "Offense, defense, and the causes of war." International Security 22.4 (1998): 5-43.

Waltz, K. Man, the State and War: a theoretical analysis. New York: Columbia U. P., 1959.

Waltz, K. Theory of International Politics. New York: Waveland, 1979.

Waltz, K. "The origins of war in neorealist theory." Journal of Interdisciplinary History 18 (1988): 615-628.

Waltz, K. “The emerging structure of international politics." International Security 18 (1993): 44-79.

Waltz, K. "Structural realism after the Cold War." International Security 25 (2000): 5-41.

Warry, J. Warfare in the Classical World. Norman: University of Oklahoma, 1995.

Wellesley, K., editor. Tacitus: Histories. London: Penguin, 1964.

Wiesehöfer, J. Die ‘Dunklen Jahrhunderte' der Persis: Untersuchungen zu Geschichte und Kultur von Fārs in frühhellenistischer Zeit (330-140 v. Chr.). Munich: C. H. Beck, $1994 \mathrm{a}$.

Wiesehöfer, J. Ancient Persia from 550 BC to 650 AD. Trans. A. Azodi. London: I. B.Tauris, 1996.

Wiesehöfer, J. "Fars under Seleucid and Parthian rule." In The Age of the Parthians, edited by V. Curtis and S. Stewart, 37-49. London: I. B. Tauris, 2007 a.

Wiesehöfer, J. "From Achaemenid imperial order to Sasanian diplomacy: war, peace, and reconciliation in pre-Islamic Iran." In War and Peace in the Ancient World, edited by K. Raaflaub, 121-140. Malden: Blackwell, 2007b.

Wiesehöfer, J. "Frataraka rule in Seleucid Persis: a new appraisal.” In Creating a Hellenistic World, edited by A. Erskine and L. Llewellyn-Jones, 107-121. Swansea: Classical Press of Wales, 2011.

Wiesehöfer, J. “Frataraka.” Encyclopaedia Iranica (2012). 5 2017. <http://www.iranicaonline.org/ articles/frataraka>.

Wiesehöfer, J. "Frataraka and Seleucids.” In Potts 2013, 718-727.

Wiesehöfer, J. "Iranian Empires." In Oxford Handbook of the State in the Ancient Near East and Mediterranean, edited by P. Bang and W. Scheidel, 199-233. Oxford: Oxford U. P., 2016.

Wiesehöfer, J. and S. Müller, editors. Parthika: Greek and Roman Authors' Views of the Arsacid Empire. Wiesbaden: Harrassowitz, 2017.

Wight, M. Power Politics. New York: Continuum, 1978.

Wilcox, P. Rome's Enemies (3): Parthians \& Sassanid Persians. Oxford: Oxprey, 1986.

Wilson, L. and G. Assar. "Re-dating Eukratides I relative to Mithradates I." Journal of the Oriental Numismatic Society 191 (2007): 24-25.

Wohlforth, W. "Realism and the end of the Cold War." International Security 19 (1994-1995): 91-129.

Wolski, J. “Les Achéménides et les Arsacides: contribution à l'histoire de la formation des traditions iraniennes.” Syria 43 (1966): 65-89. 
Wolski, J. “L’aristocratie parthe et les commencements du féodalisme en Iran.” Iranica Antiqua 7 (1967): 133-144.

Wolski, J. "Iran und Rom. Versuch einer historischen Wertung der gegenseitigen Beziehungen." Aufstieg und Niedergang der römischen Welt 2.9.1 (1976): 195-214.

Wolski, J. “La frontière orientale dans la politique de l'Iran des Arsacides." Folia Orientalia 21 (1980): 235-244.

Wolski, J. “L'aristocratie foncière et l'organisation de l'armée parthe.” Klio 63 (1981): 105-112.

Wolski, J. “Die Parther und ihre Beziehungen zur griechisch-römischen Kultur.” Klio 65 (1983): 137-149.

Wolski, J. “Dans l'attente d'une nouvelle histoire de l'Iran arsacide." Iranica Antiqua 20 (1985): 163-73.

Wolski, J. "Die gesellschaftliche und politische Stellung der großen partischen Familien.” Tyche 4 (1989): 221-27.

Wolski, J. L'Empire des Arsacides (Acta Iranica 32) - Textes et Mémoires XVIII. Leuven: Peeters, 1993.

Zakaria, F. From Wealth to Power: the unusual origins of America's world role. Princeton: Princeton U. P., 1998.

Ziegler, K. Die Beziehungen zwischen Rom und dem Partherreich: ein Beitrag zur Geschichte des Völkerrechts. Wiesbaden: Harrassowitz, 1964. 